\title{
Taxol-Induced Mitotic Block Triggers Rapid Onset of a p53-Independent Apoptotic Pathway
}

\author{
Catherine M. Woods, Jian Zhu, Patricia A. McQueney, \\ Daniel Bollag, and Elias Lazarides ${ }^{1}$ \\ Department of Pharmacology, Merck Research Laboratories, \\ West Point, Pennsylvania, U.S.A.
}

\begin{abstract}
Background: At therapeutic concentrations, the antineoplastic agent taxol selectively perturbs mitotic spindle microtubules. Taxol has recently been shown to induce apoptosis, similar to the mechanism of cell death induced by other antineoplastic agents. However, taxol has shown efficacy against drug-refractory cancers, raising the possibility that this pharmacological agent may trigger an alternative apoptotic pathway.

Materials and Methods: The kinetics and $\mathrm{IC}_{50}$ of mitotic (M) block, aberrant mitosis, and cytotoxicity following taxol treatment were analyzed in human cell lines as well as normal mouse embryo fibroblasts (MEFs) and MEFs derived from p53-null mice. Apoptosis was followed by DNA gel electrophoresis and by in situ DNA end-labeling (TUNEL).

Results: Taxol induced two forms of cell cycle arrest: either directly in early $M$ at prophase or, for those cells progressing through aberrant mitosis, arrest in $G_{1}$ as
\end{abstract}

multimininucleated cells. TUNEL labeling revealed that DNA nicking occurred within $30 \mathrm{~min}$ of the arrest in prophase. In contrast, $\mathrm{G}_{1}$-arrested, multimininucleated cells became TUNEL positive only after several days. In the subset of cells that became blocked directly in prophase, both wt p53-expressing and p53-null MEFs responded similarly to taxol, showing rapid onset of DNA nicking and apoptosis. However, p53-null MEFs progressing through aberrant mitosis failed to arrest in the subsequent $G_{1}$ phase or to become TUNEL positive, and remained viable.

Conclusions: Taxol induces two forms of cell cycle arrest, which in turn induce two independent apoptotic pathways. Arrest in prophase induces rapid onset of a p53-independent pathway, whereas $G_{1}$-block and the resulting slow (3-5 days) apoptotic pathway are p53 dependent.

\section{INTRODUCTION}

Taxol is a complex plant alkaloid with a unique taxane ring structure which appears to target microtubules (MTs) specifically both in vitro and in vivo (1-6). Taxol binds to the polymeric microtubule form of tubulin in a 1:1 stoichiometry with $\alpha \beta$-tubulin heterodimer subunits $(2,4,7)$. Binding markedly shifts the dynamic instability equilibrium of MT polymers, stabilizing against dissociation and hence augmenting polymerization. Bound taxol overrides the need for GTP hydrolysis in tubulin heterodimer polymeriza-

Address correspondence and reprint requests to Catherine M. Woods, at her present address: Alliance Pharmaceutical Co., 3040 Science Park Road, San Diego, CA 92121.

${ }^{1}$ Present address: Astral Inc., 3040 Science Park Road, San Diego, CA 92121. tion, and consequently it also serves to lower the critical concentration for tubulin polymerization $(2,7)$; in vivo this is manifested by the ability of taxol to override the centrosomal MT nucleating activity in interphase cells, resulting in the appearance of non-centrosomally linked MT bundles throughout the cytoplasm $(1,5,6,8)$. Currently, there has been considerable interest in taxol as a cancer therapeutic agent, in particular because it has shown activity against leukemias, late stage ovarian, and metastatic breast cancers refractory to standard chemotherapeutic treatments (9-12). Phase I and II trials have also shown some efficacy against advanced small cell lung cancer (13), melanoma $(14,15)$ and head and neck cancers (16).

Microtubules constitute a major class of 
structural filaments in the eukaryotic cell and play a key role in a wide repertoire of cellular processes: endocytosis, vesicular movement, cell morphology and motility, and mitosis to name but a few (17). Somewhat surprisingly, however, taxol concentrations within the therapeutic range are not necessarily sufficient to cause gross rearrangements of interphase MT arrays and leave a functional MT scaffold intact. Therefore, it is not immediately apparent why taxol should be cytotoxic rather than merely cytostatic. In cultured human cell lines, taxol has been shown to induce a block in the cell cycle at the $G_{2} / M$ transition $(1,18-23)$. At the $G_{2} / M$ transition, cellular MTs undergo a dramatic reorganization associated with a sudden change in the centrosomal MT-nucleating activity $(5,6,23,24)$. Interphase MTs dissociate (even in the presence of taxol) as the centrosomes concurrently elaborate the mitotic spindle MTs $(5,6,23,24)$. Interestingly, this sudden change in centrosomal activity correlates with association of $\mathrm{p} 34^{\mathrm{cdc} 2} /$ cyclin B complex with the centrosome $(23,25)$. Taxol induces aberrant multipolar spindle formation that causes mitotic arrest $(5,6,26)$. Recent studies with human lines have provided strong evidence that it is this arrest in $M$ that correlates with cytotoxicity $(18,20-22,27,28)$. For HeLa cells, the $\mathrm{EC}_{50}$ for arrest at the $\mathrm{G}_{2} / \mathrm{M}$ transition is similar for the $\mathrm{EC}_{50}$ for taxol-induced cytotoxicity and 1 to 2 orders of magnitude lower than the doses required to induce gross changes in interphase MT arrays (18). Rodent cells are also sensitive to taxol in ranges that perturb mitosis but appear to be more tolerant of arrest in mitosis; they eventually assume a multimininucleated phenotype resulting from aberrant mitosis and lack of cytokinesis. Doses effecting these changes are also cytotoxic $(5,6,19)$. Species differences between human and rodent lines have been attributed to differences in $\mathrm{p} 34^{\mathrm{cdc} 2}$ regulation (19). Taken together, these studies predict that taxol should be therapeutically active only against cells that are rapidly cycling. In balance, this appears to be the case, and the side effects of neutropoenia and leukopoenia as well as gastrointestinal-related side effects have been shown to be consistent with the hypothesis that taxol effects are due to mitotic arrest $(29,30)$. However, exceptions exist where tumor regression is found despite the lack of actively cycling tumor cells and studies with leukemic lines have indicated that sensitivity to taxol correlates with the induction of MT bundles rather than multipolar aster formation
$(8,31)$. Therefore, the nature of taxol's therapeutic activity remains to be fully elucidated.

Cell death can be induced by either necrosis or an active process known as apoptosis (32-36). The latter appears to be closely linked to the programmed cell death that occurs in development (32-35). Typically, high levels of insult induce necrosis, whereas lower levels induce apoptosis $(33,35,36)$. In several cases of cellular differentiation, growth factors serve not only as proliferative and differentiating signals but also serve to rescue precursor proliferating cells from apoptosis (33-35). Thus certain cell types, most dramatically cells of the hematopoetic lineages, are particularly poised for apoptosis (low threshold for apoptosis defined in Refs. 33 and 35). It has now been well established that DNA-damaging cancer therapeutics and $\gamma$-irradiation exert their cytotoxic effects by inducing the programmed apoptotic pathway following arrest in $G_{1}$ or $G_{2}$ as opposed to necrosis $(36-42)$. The tumor suppressor, $\mathrm{p} 53$, has been shown to play a key role in this process. The process of DNA nicking in and of itself induces elevated p 53 levels $(43,44)$ which in turn induce $G_{1}$ arrest by up-regulation of the cdk inhibitor WAFl/Cipl/ p2 1 (45-48) to prevent progression past the $G_{1} / S$ checkpoint of cells with damaged DNA. Extensive DNA damage leads to prolonged $G_{1}$ arrest and apoptosis (43). Similarly, commonly used antineoplastic agents that target DNA, which induce arrest in $G_{1}$ or $G_{2}$, trigger the same p53 response (42-44,49-55). Interestingly, many advanced stage tumor types which have poor prognosis with established antineoplastic therapies express a high percentage of p53 mutations (55-59). For many tumor types, a late stage event in the progression of the cancer is the clonal expansion of cells expressing mutant p53 alleles (55-59). Mutation of the normal cellular p53 gene has been shown to be sufficient to induce cellular immortalization $(55,59,60)$ and can enhance tumorigenicity (61-64). p53 normally functions as a homo-oligomer; hence, a single mutant p53 allele can lead to a dominant negative phenotype $(63,65)$. The discovery that Li Fraumeni patients, genetically predisposed to an abnormally high incidence of cancer, fail to mount a normal p53-mediated response, together with studies indicating that transgenic mice carrying germ line knock-out of p53 alleles are more prone to develop spontaneous cancers and fail to mount an appropriate apoptotic response to $\gamma$-irradiation or DNA-damaging antineoplastic agents, provides strong support for the 
hypothesis that $\mathrm{p} 53$ plays an important role in the apoptotic pathways underlying elimination of $a b-$ errant tumor cells $(42-44,49,50,52-55,61,66,67)$. Alternative non-p53-dependent apoptotic pathways also exist. These operate in normal development; for example apoptosis resulting from growth-factor deprivation appears to occur via a p53-independent pathway $(33,35,52,54,68)$. Since taxol induces predominantly arrest in early $M$ rather than $G_{1}$ or $G_{2}$ arrest in human cells, it is of interest to know whether the apoptotic pathway triggered by taxol (69-71) is dependent on p53.

Here we describe detailed comparative analyses of taxol effects on several human carcinoma lines as well as a normal human line. Kinetic analysis reveals that the majority of human cells become blocked at the $G_{2} / M$ transition in prophase, with only a small percentage progressing through a protracted aberrant mitosis, manifested by a multimininucleated phenotype, to become arrested in the subsequent $G_{1}$ stage. The lag between mitotic block and cell death is $20-30 \mathrm{hr}$, with similar $\mathrm{EC}_{50}$ values for both processes. $G_{1}$-arrested multimininucleated cells are also destined to die but with much slower kinetics (several days). We further demonstrate that both forms of taxolinduced cell cycle arrest lead to apoptosis. However, apoptosis triggered by arrest in $M$ is initiated very rapidly, within $30 \mathrm{~min}$ of arrest at prophase, and appears to operate by a p53independent pathway. In contrast, both the $G_{1}$ arrest and subsequent apoptotic death of cells progressing through an aberrant mitosis are p53 dependent.

\section{MATERIALS AND METHODS Cells}

Hela, Hs578T, Hs578Bst, MCF7, and Ratl cells were all obtained from ATCC and each grown in the medium specified by ATCC at $37^{\circ} \mathrm{C}$ in a humid atmosphere containing $5 \% \mathrm{CO}_{2}$. wt p53 Mouse embryo fibroblasts (MEFs) were isolated by trypsinizing the muscle mass of 13-day mouse embryoes, filtering through $70-\mu \mathrm{m}$ filters and plating at $0.3 \times 10^{6}$ cells per $\mathrm{cm}^{2}$ in DMEM (Gibco, Gaithersburg, MD, U.S.A.) containing $10 \%$ FBS (ICN) and $1 \times$ penicillin/streptomycin (Gibco). After $1 \mathrm{~h}$ nonadherent cells were removed. MEFs were passaged twice before being used for experiments. MEFs lacking p53 (p53-/- MEFs) were obtained from T. Jacks (MIT). p53 status was verified by
Western blot analyses. For comparative nuclear and viability/growth analyses, cells were seeded both in 48 -well plates at $2.5 \times 10^{4}$ cells per well (for viability and cell counting) and onto \#1 glass coverslips in 6-well plates at $5 \times 10^{5}$ cells per well (for mitotic scoring). Twenty-four hours later, the medium was replaced with medium containing taxol at the specified concentrations. Taxol was always added directly from a DMSO stock to prewarmed medium immediately prior to treating the cells; final DMSO concentration was always less than $0.1 \%$. DMSO up to $1 \%$ had little effect on cell growth. At specified times, nonadherent cells were collected and the adherent cells trypsinized. After pelleting briefly at 2,000 rpm for $2 \mathrm{~min}$ in an Eppendorf centrifuge, the cell pellet was resuspended in a final volume of 50-100 $\mu \mathrm{l} \mathrm{2 \%}$ Trypan blue in PBS. Concurrently, coverslips were fixed in Omnifix for $10 \mathrm{~min}$ then stained with $2 \mu \mathrm{g} / \mathrm{ml}$ Hoechst 33342 (Boehringer-Mannheim, Indianapolis, IL) in PBS. To assay cells in suspension, $0.5 \mathrm{ml} \mathrm{me-}$ dium was removed after very gentle swirling, cells pelleted and stained in $2 \mu \mathrm{g} / \mathrm{ml}$ Hoechst in $30 \%$ ethanol. Stained cells were viewed under epifluorescence with a Zeiss Axiophot microscope. Two sets of 250 cells, located by random walk of the stage control, were scored as prophase, mitotic, multimininucleated or normal interphase for each time point. The ratio of attached to nonadherent cells derived from the total cell counts was used to convert scoring of Hoechst-stained adherent and nonadherent cells to overall percentages in the total population.

To obtain cells synchronized in the cell cycle, mitotic cells were collected by selective shake-off from 70 to $80 \%$ confluent (higher densities helped minimize detachment of interphase cells) $\mathrm{HeLa}$ cells with two successive 7 -min incubations at $37^{\circ} \mathrm{C}$ in $\mathrm{Ca}^{2+}$ and $\mathrm{Mg}^{2+}$-free Hanks' buffered salt solution (CMF-HBSS; $37^{\circ} \mathrm{C}$ ). Harvested cells were cooled to $15^{\circ} \mathrm{C}$ to arrest cells in mitosis without depolymerizing the MTs, and collected by centrifugation at $15^{\circ} \mathrm{C}$ for $5 \mathrm{~min}$ at $1000 \times \mathrm{g}$. A small aliquot of cells was fixed and Hoechst-stained to assess percent mitotic cells and the remainder plated onto coverslips or incubated as required. Only preparations exceeding $50 \%$ mitotic cells were used for experiments.

\section{End Labeling of Cellular DNA and Agarose Gel Electrophoresis}

Cellular DNA was isolated from cells at different times following taxol treatment by proteinase $\mathrm{K}$ and RNAaseA digestion of cell lysates followed 
by phenol chloroform extraction and ethanol precipitation following standard protocols. DNA was end labeled with ${ }^{32} \mathrm{P}-\gamma$ ATP using terminal transferase (Boehringer Mannheim), electrophoresed on a $1.4 \%$ agarose gel and transferred to nitrocellulose. The dried blot was exposed to Kodak X-OMAT film for $15-30 \mathrm{hr}$ at $-80^{\circ} \mathrm{C}$.

\section{TUNEL Labeling and Immunofluorescence}

For tubulin immunofluorescence (IF) cells were fixed in $-20^{\circ} \mathrm{C}$ methanol and processed for IF using anti- $\beta$ tubulin mAbs (Amersham, Arlington Heights, IL). For labeling DNA ends in situ, the TUNEL method described by Gavrieli et al. (72) was modified as follows. Cells were fixed for $5 \mathrm{~min}$ in $2 \%$ formaldehyde in TBS (10 mM Tris $\mathrm{HCl}(\mathrm{pH} 8.0), 100 \mathrm{mM} \mathrm{NaCl}, 1 \mathrm{mM} \mathrm{MgCl}{ }_{2}, 1 \mathrm{mM}$ EDTA) and permeabilized in $0.5 \%$ Triton X-100 in TBS for $15 \mathrm{~min}$. After successive washes in TBS and TTD buffer ( $100 \mathrm{mM}$ Na cacodylate $(\mathrm{pH}$ 6.6), $5 \mathrm{mM} \mathrm{CoCl}_{2}, 0.26 \mathrm{mg} / \mathrm{ml} \mathrm{BSA}$ ) cells were end-labeled with terminal transferase using digitonin-coupled dUTP (Boehringer Mannheim) followed by counter labeling with FITC-conjugated mouse anti-digitonin mAbs as described (Boehringer Mannheim). For this application of terminal transferase activity, we found considerable variation in enzyme batches. To ensure consistent results the following control was included. Fixed cells were treated with $50 \mu \mathrm{l} / \mathrm{ml}$ micrococcal nuclease (Boehringer Mannheim) in $10 \mathrm{mM}$ Tris $\mathrm{HCl}(\mathrm{pH} 8.5), 1 \mathrm{mM} \mathrm{MgCl}_{2}, 1 \mathrm{mM}$ $\mathrm{CaCl}_{2}$ for $20 \mathrm{~min}$ and then processed for TUNEL labeling as described above. Only enzyme batches that yielded clean nuclear staining following this treatment were used for these experiments. In addition, etoposide treated cells were also used as controls for a positive reaction. To assess the kinetics of DNA nicking following taxol-induced arrest at the $\mathrm{G}_{2} / \mathrm{M}$ transition, mitotic cells harvested by selective shake-off were plated onto coverslips and incubated for $10 \mathrm{hr}$ at $37^{\circ} \mathrm{C}$. One hundred nanomolar taxol was then added and after an additional 3-4 hr, coverslips were collected at 30-min intervals, fixed, processed for TUNEL staining, and counterstained with Hoechst 33342. Nonadherent cells were also processed. Two sets of 250 cells per coverslip were scored. Control untreated cells typically exhibited a peak of mitosis between 16-17 hr after the shake-off.

\section{RESULTS}

\section{Kinetics of Mitotic Block and Cytotoxicity Following Taxol Treatment}

To establish the correlation between mitotic block and cell death and the kinetics between these two events, different human cell lines, including HeLa (human cervical carcinoma), Hs578T and MCF-7 (human breast adenocarcinoma), and Hs578Bst (derived from normal breast tissue) were treated with $10^{-9}$ to $10^{-6} \mathrm{M}$ taxol. Care was taken to score both attached and detached cells for cell number and mitotic state since prolonged mitotic block (>3-4 hr) caused cells to detach irreversibly from the substratum since even if these detached prophase cells were transfered to another well, they failed to attach. The results obtained for HeLa cells are shown in Fig. 1. A lag of three-four hr elapsed after taxol addition before a statistically significant increase in the percent of cells in mitosis compared with the controls $(\sim 3 \%)$ was observed. The estimated time to complete mitosis is $20-30 \mathrm{~min}$ (24). HeLa cells have a doubling time of around $16 \mathrm{hr}$, therefore, at any one time the number of cells predicted to be in $\mathrm{M}$ should be $2.1-3.1 \%$. This predicted value corresponded exactly to the observed value scored for the untreated cells of 3.1

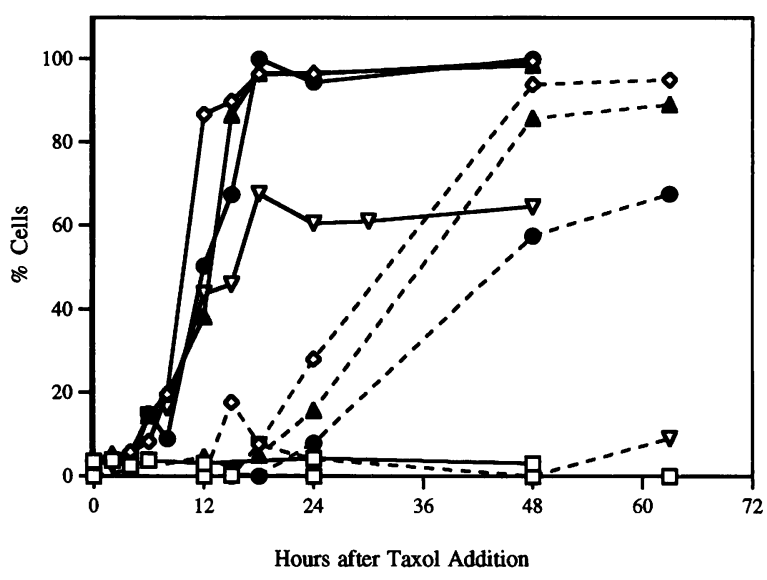

FIG. 1. Kinetics of taxol-induced block in mitosis and cytotoxicity in HeLa cells

Cells were treated with $1 \mu \mathrm{M}(\diamond), 100 \mathrm{nM}(\Delta), 25 \mathrm{nM}$ $(\Theta), 10 \mathrm{nM}(\nabla)$, or $0(\square)$ taxol and scored at intervals for arrest in prophase by Hoechst staining (solid lines) or cell death by Trypan blue staining (dashed lines). Both attached and detached cells were scored, since cells arrested in prophase soon detach, and summed to give the total cell number. The ratio of cell numbers attached:detached was used to calculate overall percentage of cells in $M$. 

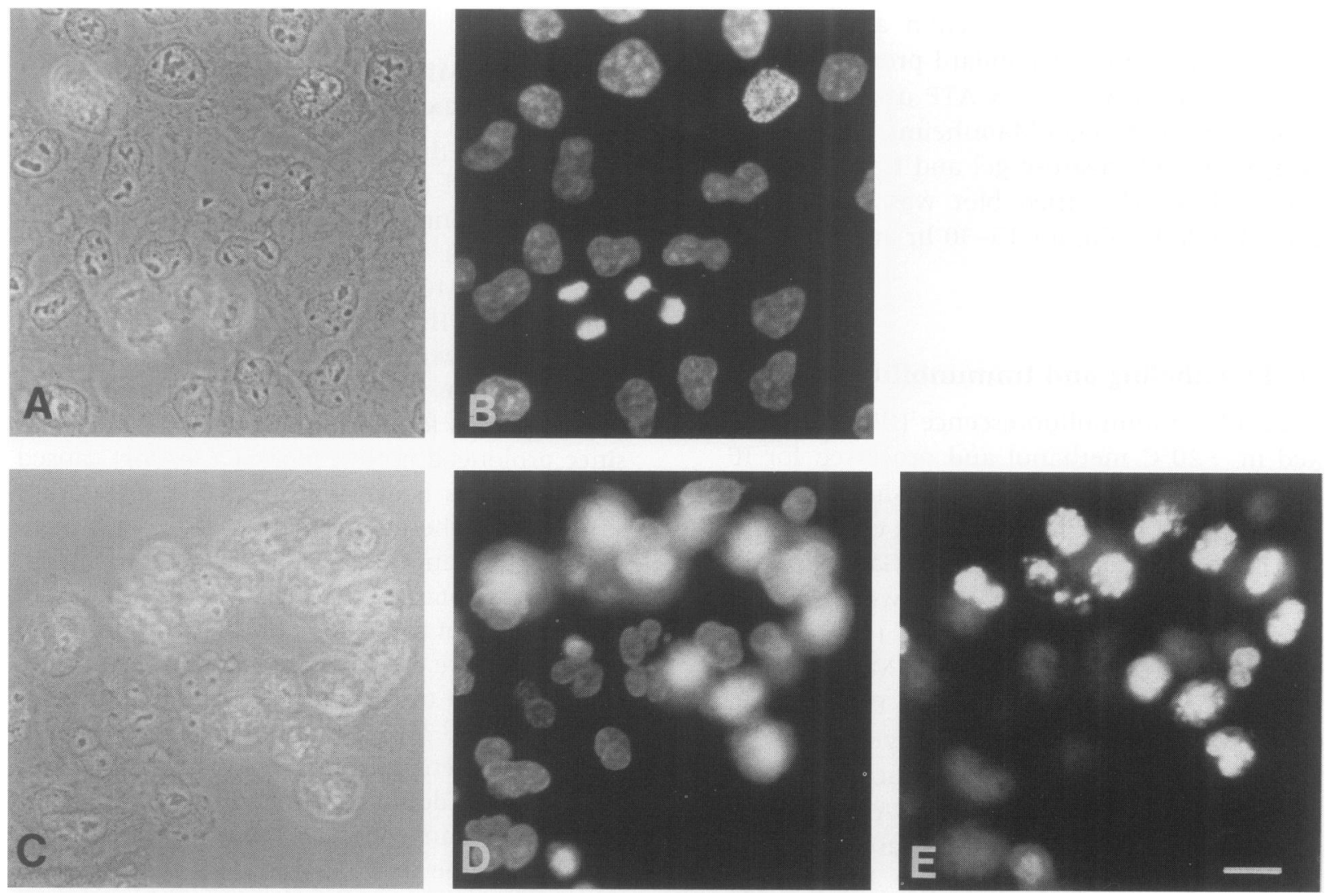

FIG. 2. Taxol induces either arrest in prophase or multimininucleation

HeLa cells were grown on \# 1 coverslips, and fed regular medium (Control; A and B) or treated with $100 \mathrm{nM}$ taxol for $24 \mathrm{hr}(\mathrm{C}-\mathrm{E})$. Cells were stained with Hoechst 33342 (B, D, and E) and viewed with epifluorescence. The corresponding phase is shown in the left-most panel. Panel E shows prophase-blocked cells in focus; Panel D shows the same field but with the attached interphase cells in focus. Bar in Panel E represents $10 \mu \mathrm{m}$; magnification is the same for all panels.

$\pm 0.3 \%$. Should taxol immediately effect mitotic block, the rate of accumulation in $M$ for the whole population should reflect these kinetics. Therefore the lag between taxol addition and onset of mitotic block indicated either that a minimum time was required to accumulate sufficient intracellular taxol to reach an adequate MT-taxol equilibrium to induce this effect or that time was required for some downstream effects to be manifested. Short, 1-hr taxol treatments revealed that a similar pattern of lag followed by accumulation in $M$ could be observed for the first 8-15 hr (depending on taxol concentration) indicating that the lag was due to some downstream effect (data not shown).

From $4 \mathrm{hr}$ onwards, progressively more cells became blocked in prophase (i.e., at the $\mathrm{G}_{2} / \mathrm{M}$ transition), at a rate consistent with the doubling time exhibited by the untreated cells. For Hela cells treated with $\geq 100 \mathrm{nM}$, more than $95 \%$ of the cells became blocked in prophase within 15-18 hr, equivalent to the doubling time of the cells (Figs. 1 and 2E). Cell death commenced 24-36 hr later, as evidenced by Trypan blue exclusion, with the slope of taxol-induced cytotoxicity ressembling that of mitotic block at taxol concentrations at or above $25 \mathrm{nM}$ (Fig. 1). At concentrations around the $\mathrm{IC}_{50}$ and below, this relationship is obscured when the data is expressed on a percentage basis since from 2 to 3 days onwards, the cells that passage through $M$ normally continue to rapidly proliferate (see below). A small percentage of the residual attached cells was seen to be multimininucleated (Fig. $2 \mathrm{E})$. These cells were observed at taxol concentrations of 10 to $25 \mathrm{nM}$ and amounted to less than $5 \%$ of the total cell number. At these concentrations a few mitotic figures were observed that had proceeded past the block at prophase to metaphase, but they displayed grossly misaligned 
TABLE 1. Comparison of $\mathrm{EC}_{50}$ values for mitotic arrest and cytotoxicity induced by taxol in various human cell lines

\begin{tabular}{lccc}
\hline Cell Type & $\begin{array}{c}\text { Mitotic Arrest } \\
(\mathrm{nM})\end{array}$ & $\begin{array}{c}\text { Aberrant Mitosis }^{a} \\
(\mathrm{nM})\end{array}$ & $\begin{array}{c}\text { Cytotoxicity }^{b} \\
(\mathrm{nM})\end{array}$ \\
\hline Hela & $8.4 \pm 1.5$ & $8.4 \pm 1.5$ & $25.6 \pm 5.6$ \\
Hs578T & $16.6 \pm 7.6$ & $10.0 \pm 5.3$ & $14.8 \pm 4.9$ \\
Hs578Bst & $18.5 \pm 6.5$ & $12.5 \pm 0.5$ & 10.0 \\
MCF-7 & $6.7 \pm 1.7$ & $6.7 \pm 0.5$ & $47.0 \pm 7.2$ \\
& & & \\
\hline
\end{tabular}

All individual curve fits gave $R^{2}$ values of 0.98 to 1.0 . Cells were treated with taxol concentrations ranging from 1 to $0 \mu \mathrm{M}$ and scored after ${ }^{a} 24 \mathrm{hr}$ for mitotic effects as described in Materials and Methods.

${ }^{b}$ Cytotoxicity estimations based on \# Trypan blue positive cells after $72 \mathrm{hr}$. Data was analyzed by Inplot or Prism (Graphpad, CA, U.S.A.) to obtain $\mathrm{EC}_{50}$ values. Experiments were carried out in triplicate.

chromosome arrays (Fig. 3I). Detailed microscopy observations indicated that multimininucleation was the consequence of passage through aberrant mitosis, with the individual mininuclei apparently resulting from lamin repolymerization and nuclear envelope reformation occurring around each misaligned clump of chromosomes. Noticeably, multimininucleated cells were not observed until at least $18 \mathrm{hr}$ in the presence of taxol. These cells became arrested in the subsequent $G_{1}$ stage, as evidenced by the constant amount of Hoechst-stained chromatin seen immediately after their first appearance and at all subsequent time points. Multimininucleated cells also died but with much slower kinetics of 3-6 days following $G_{1}$ arrest.

Similar correlations between taxol-induced cell cycle arrest and cytotoxicity were also seen with the Hs578T, MCF7, and Hs578Bst lines (doubling time of 2,3, and 7 days, respectively). With the slower growing MCF7 and Hs578Bst cultures, it was clear that taxol only remained effective for the first $24-48 \mathrm{hr}$ following addition of taxol-containing medium. Cells entering $M$ around $48 \mathrm{hr}$ appeared to be only transiently blocked in this phase of the cell cycle, passaging through aberrant $M$ to arrested in the cell cycle as multimininucleated cells. Thereafter, cells entering $M$ progressed through normal mitosis. Addition of fresh taxol to the medium at this point was required to block the next cohort of cells entering $M$, confirming that taxol remained effective only for a limited time in slower growing cell lines (data not shown). However, within the time period taxol remained fully effective, it exerted a similar effect on all the human lines we analyzed, namely, selective perturbation of mi- tosis, which in turn induced arrest at one of two stages of the cell cycle. The majority of cells were blocked directly in $\mathrm{M}$ (mitotic arrest in Table 1) and died 24-48 hr later. The remaining cells that did progress through $\mathrm{M}$ (aberrant mitosis in Table 1 represents the sum of $\mathrm{M}$-blocked plus cells that pass through abberant $M$ to become multimininucleated) appeared to become arrested in $G_{1}$, based on the constant chromatin content contained by these multimininucleated cells immediately following their appearance (i.e., bona fide $G_{1}$ ) and at all subsequent time points. This $G_{1}$ arrest was confirmed by FACS analysis for MCF7 and Hs578T cells (these cell lines exhibited a greater fraction of multimininucleated cells than did HeLa cells) since no progression past the 4N DNA compartment was observed in the adherent multimininucleated cell population (data not shown). These $G_{1}$-arrested multimininucleated cells died after 3-6 days.

Anti-tubulin IF revealed that $2-4 \mathrm{hr}$ of exposure to taxol above $10 \mathrm{nM}$ induced abnormal multipolar spindles in the prophase-blocked cells (Fig. $3 \mathrm{C}$ and D) compared with the normal bipolar spindle arrays of untreated cells (Fig. 3B). In contrast, gross rearrangements of MT arrays in interphase cells required concentrations in the $1-10 \mu \mathrm{M}$ range $(5,6,73)$. As shown in Table 1 , the $\mathrm{EC}_{50}$ values for taxol-induced cytotoxicity at $72 \mathrm{hr}$ correlated with the $\mathrm{EC}_{50}$ for arrest in early $M(7-18.5 \mathrm{nM})$ and were two orders of magnitude lower than the 1-10 $\mu \mathrm{M}$ concentrations required for gross perturbations of interphase MT arrays (73). The $\mathrm{EC}_{50}$ values for $\mathrm{M}$ arrest and cytotoxicity were similar for all human lines examined. No difference was noted between the 

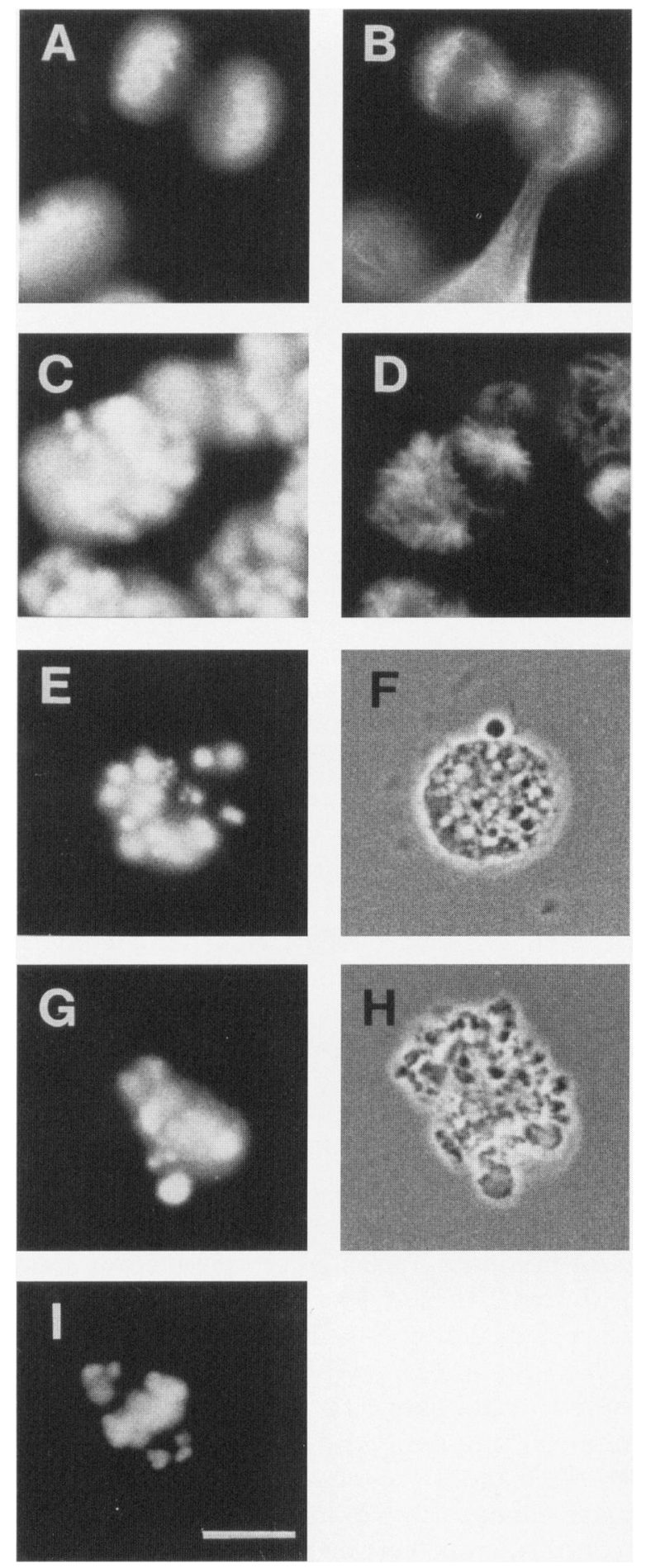

tumor-derived lines and the Hs578Bst line derived from normal breast tissue.

\section{Taxol-Induced Cytotoxicity Occurs by an Apoptotic Pathway}

Microscopic observations of Hoechst-stained cells, indicated that initially cells blocked by taxol
FIG. 3. Sequence of changes induced by taxol in HeLa cells

Untreated (A and B) and taxol-treated (4 hr; C and D) cells processed for anti-tubulin IF (B and D) and counterstained with Hoechst 33342 nuclear dye (A and $C$ ) to reveal multipolar spindles induced by taxol. A few cells undergo aberrant mitosis exhibiting irregular chromosome arrays at metaphase (I). After 24-hr taxol treatment, Hoechst staining reveals DNA becomes globular (E and G Hoechst staining; $F$ and $\mathrm{H}$ corresponding phase) especially when cells have extensive membrane blebbing $(\mathrm{H})$. Exposure times for Panels $E$ and $G$ were shorter than for Panels A, C, and I. Bar in Panel I represents $10 \mu \mathrm{m}$; magnification is the same for all panels.

in prophase displayed defined chromatin structure (Fig. 3C; note that this 3D structure cannot be illustrated well by a single plane of focus, given the tightly compacted nature of the chromatin, but the structure was clearly evident with fine focussing up and down through several optical planes). However, by $24 \mathrm{hr}$ following addition of taxol, the chromatin of many cells began to appear globular and more brightly stained (Fig. $3 \mathrm{E}$ and corresponding phase image F; note, the exposure times for Panels $E$ and $G$ were reduced compared with Panels A, C, and I). The chromatin became progressively more globular as the cells exhibited extensive membrane blebbing and appeared phase-dense (Fig. $3 \mathrm{G}$ and $\mathrm{H}$ ). This highly globular and intensely staining DNA pattern was reminiscent of the late sequence of events seen in etoposide-treated cells used as a positive control for apoptosis. However, etoposide-treated cells become arrested in interphase at $G_{1}$ and exhibit a well-characterized sequence of apoptotic changes in chromatin morphology, initially developing punctate chromatin staining under the nuclear membrane but becoming progressively more globular and brightly Hoechststained as the nuclear structure breaks down (see Fig. $5 \mathrm{G}$ and $\mathrm{H}$ ). Therefore, etoposide-treated cells are not directly comparable to taxol-treated cells arrested in $M$. We therefore carried out gel electrophoresis with ${ }^{32} \mathrm{P}$-end labeled DNA extracted from taxol-treated cultures to detect DNA ladders, the commonly used hallmark of apoptosis $(33,34,36)$. We employed end labeling to visualize fragments on a molar basis and increase sensitivity to pinpoint the earliest time apoptosis could be monitored by gross DNA fragmentation. Figure 4 shows the results obtained with HeLa cells although identical results were also obtained with Hs578T and MCF-7 cells (data not 


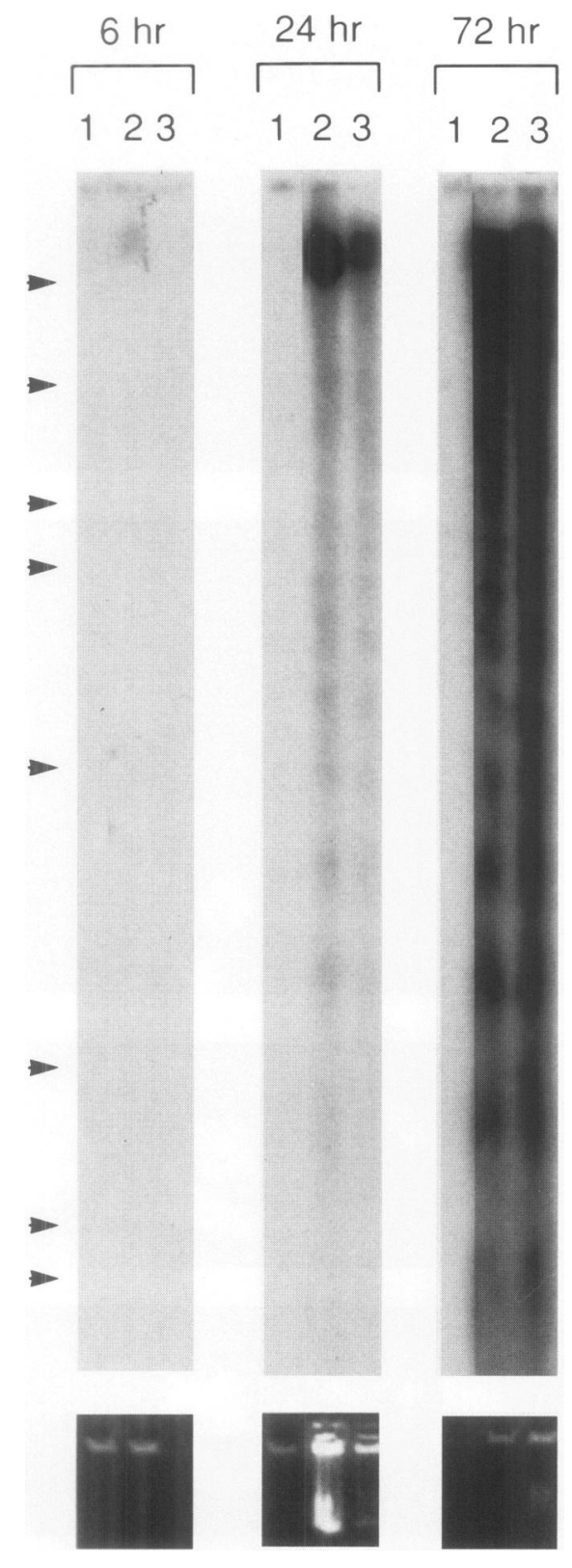

FIG. 4. Taxol induces the DNA nucleosomal ladders that are indicative of apoptosis

DNA isolated from cells treated with 0 (Lane 1), $1 \mu \mathrm{M}$ (Lane 2), or $100 \mathrm{nM}$ taxol (Lane 3) for 6, 24, or $72 \mathrm{hr}$ as indicated above the lanes. Arrowheads indicate positions of $1 \mathrm{~kb}$ ladder markers (GibcoBRL). Panels underneath represent Ethidium bromide staining of the same gel prior to transfer.

shown). No evidence for DNA fragmentation was observed after $6 \mathrm{hr}$ taxol treatment and DNA fragmentation was only evident after $24 \mathrm{hr}$ at either $100 \mathrm{nM}$ or $\mu \mathrm{M}$ taxol. Pronounced DNA ladders were only evident after $72 \mathrm{hr}$, which corresponded to the time the cells became Trypan blue positive.
Bulk DNA analysis does not reveal whether apoptosis is selectively occuring in those cells that are blocked in $M$ at prophase. To address this issue we performed in situ digitonin-dUTP endlabeling (TUNEL, 72). Since enzyme batches were highly variable in this assay, and the procedure was found to be very sensitive to permeabilization and fixation conditions, we routinely used as a control, normal cells that had been briefly treated for $20 \mathrm{~min}$ with $50 \mu \mathrm{l} / \mathrm{ml} \mathrm{miccro-}$ coccal nuclease after fixation before being processed for TUNEL labeling (Fig. $5 \mathrm{I}$ and J). Only batches of terminal transferase that gave uniformly bright-staining nuclei after in situ nuclease digestion were used. (It should be noted that poor permeabilization and enzyme penetration resulted in only peripheral labeling around the perimeter of the nucleus, again underscoring the importance of internal controls for this technique). TUNEL labeling revealed that indeed only those taxol-treated cells blocked in prophase stained positively (Fig. 5 D-F). To ensure that the preferential staining of blocked prophase cells was not simply due to more efficient enzyme penetration in mitotic cells due to dissolution of the nuclear envelope and because the chromatin is condensed, we rigorously analyzed many fields of control cells and found all untreated mitotic cells at all stages of mitosis to be TUNEL negative (Fig. $5 \mathrm{~A}-\mathrm{C}$, indicated by $\mathrm{m}$ ). Only the occasional dead cell stained positively in untreated populations (Fig. $5 \mathrm{~A}-\mathrm{C}$, indicated by arrowhead). It was also readily apparent that all $M$-blocked cells appeared to be positive even though $8 \mathrm{hr}$ of treatment was well before the time cell death was apparent by Trypan blue staining or DNA ladders were evident by gel electrophoresis. TUNEL labeling and staining of the multimininucleated cells confirmed morphological observations of Hoechst-stained cells which indicated that these cells also progressed to an apoptotic pathway of cell death. However, multimininucleated cells only began to exhibit positive TUNEL staining from 3 days onwards after $\mathrm{G}_{1}$ arrest in a much more staggered fashion (Fig. $5 \mathrm{~K}$ and L; Hs578T cells are shown since multimininucleation was more common in these cells than in HeLa cells which have a rapid doubling time).

The remarkable concordance between the number of M-blocked and TUNEL-positive cells implied that DNA nicking was induced rapidly after block in prophase. To establish the exact timing for onset of DNA nicking after arrest in $M$, cells were synchronized in the cell cycle by se- 

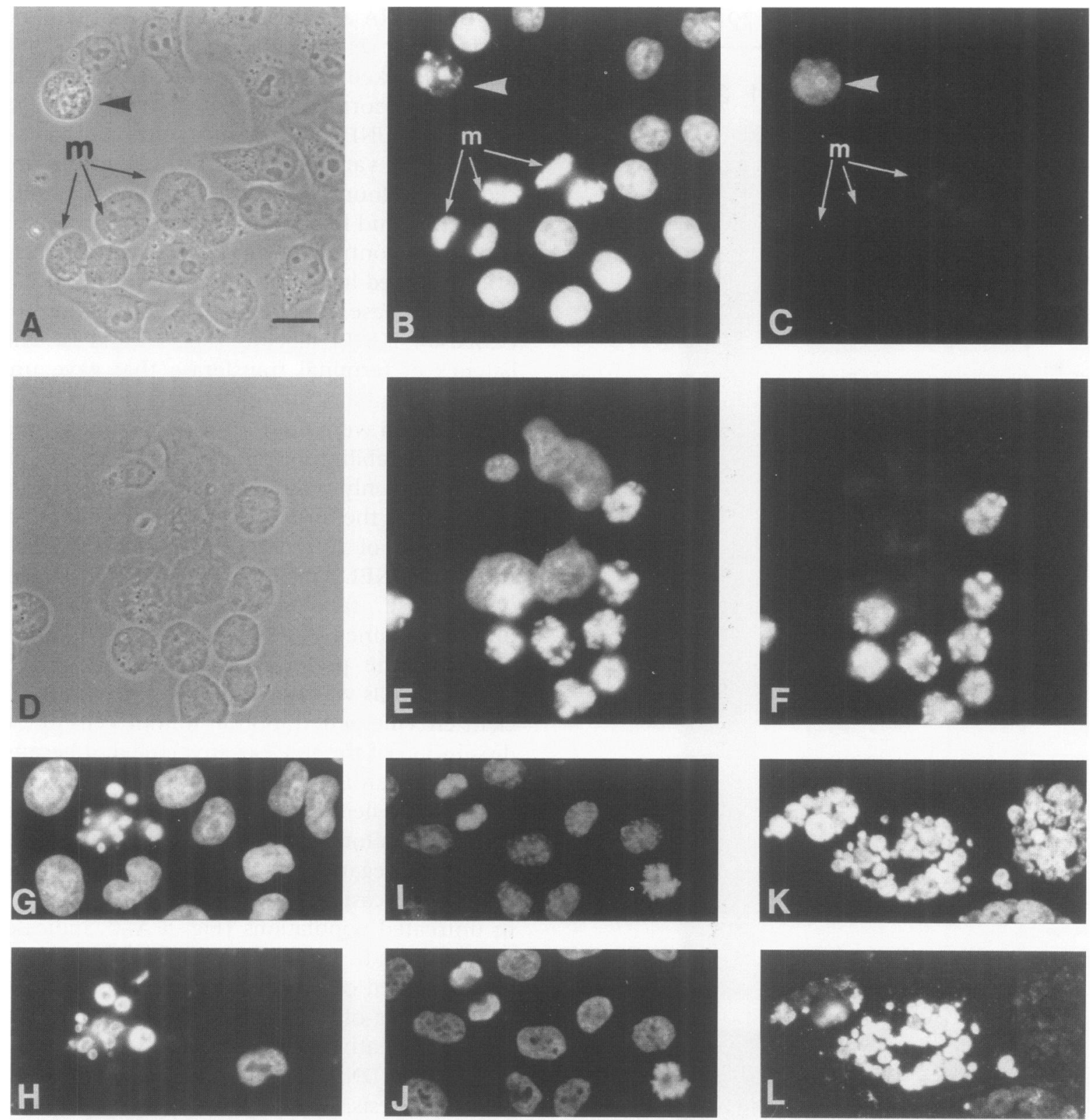

FIG. 5. TUNEL staining for in situ identification of apoptotic cells reveals that DNA nicking is detected first in taxol-treated cells blocked in prophase.

HeLa cells grown on coverslips in normal medium (A-C, I and J) or treated with $100 \mathrm{nM}$ taxol for $8 \mathrm{hr}$ (D-F) or $100 \mathrm{nM}$ etoposide for 3 days ( $\mathrm{G}$ and $\mathrm{H}$ ), as well as multimininucleated $\mathrm{G}_{1}$-arrested Hs578T cells remaining attached after 4 days following $25 \mathrm{nM}$ taxol treatment ( $\mathrm{K}$ and $\mathrm{L}$ ) were processed for TUNEL labeling of nicked DNA (C, F, H, J, and L) and counterstained with Hoechst 33342 (B, E, G, I, and K). Cells in Panels I and J were treated with micrococcal nuclease for $20 \mathrm{~min}$ after fixation and prior to TUNEL labeling. Bar in Panel A represents $10 \mu \mathrm{m}$; magnification is the same for all panels.

lective shake-off of mitotic cells. Although the yield is low using this method, it was imperative not to use any artificially induced block that in itself could trigger or prime the cells for apoptosis. The cells were then plated onto coverslips and incubated for $10 \mathrm{hr}$ before being treated with $100 \mathrm{nM}$ taxol. This timing was chosen to permit the cells obtained by selective shake-off maximal time for normal culture before entry into $M$, yet compensate for the lag effect ( $4 \mathrm{hr}$, see above) for taxol to effect $M$ block. After a further $3 \mathrm{hr}$, coverslips were collected at 30-min intervals. Control cells entered mitosis around $16 \mathrm{hr}$ after the shake-off. Using this approach more than 


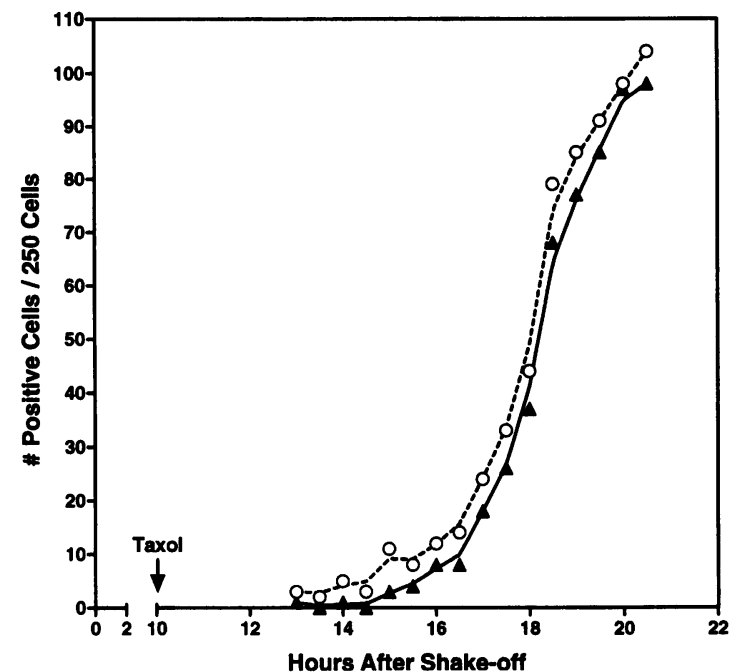

FIG. 6. Time course for onset of block in prophase (o) and appearance of TUNEL positive cells $(\Delta)$ in cell-cycle synchronized cell cultures.

TUNEL staining occurred exclusively in cells blocked in prophase. Cells were plated onto coverslips immediately after shake-off $(60 \%$ cells in mitosis by Hoechst staining). After $12 \mathrm{hr}, 200 \mathrm{nM}$ taxol was added and coverslips collected at the indicated time points, fixed, processed for TUNEL, and counterstained with DAPI. Two sets of 250 mitotic cells were scored concurrently for arrest in prophase and TUNEL staining.

$50 \%$ of the cells entered $M$ as a cohort over a $2-5$ hr period enabling the lag between arrest in prophase and appearance of TUNEL-positive cells to be accurately measured. As shown in Fig. 6 , the lag between block in $M$ and appearance of TUNEL-positive cells was remarkably short. The delay between the two curves is only $\sim 30$ mins.

\section{p53 Plays a Role in $\mathbf{G}_{1}$ Arrest Following Aberrant Mitosis but Does Not Affect Taxol-Induced Cell Death Following Arrest in $M$}

p53 plays a major role in the transducing sequence leading to apoptosis following DNA damage $(39-42,50,52,62)$. To determine whether p53 is involved in taxol-mediated apoptosis, we compared the effects of taxol on arrest in early $\mathrm{M}$, aberrant mitosis (scored by multimininucleation) and loss of viable cells in wt p53 MEFs to those in p53-null MEFs derived from p53-1transgenic mice $(39,53)$. Not surprisingly, the status of p 53 had no effect on taxol's primary biological mode of action, namely perturbation of mitotic MTs. Hence, block in prophase (solid
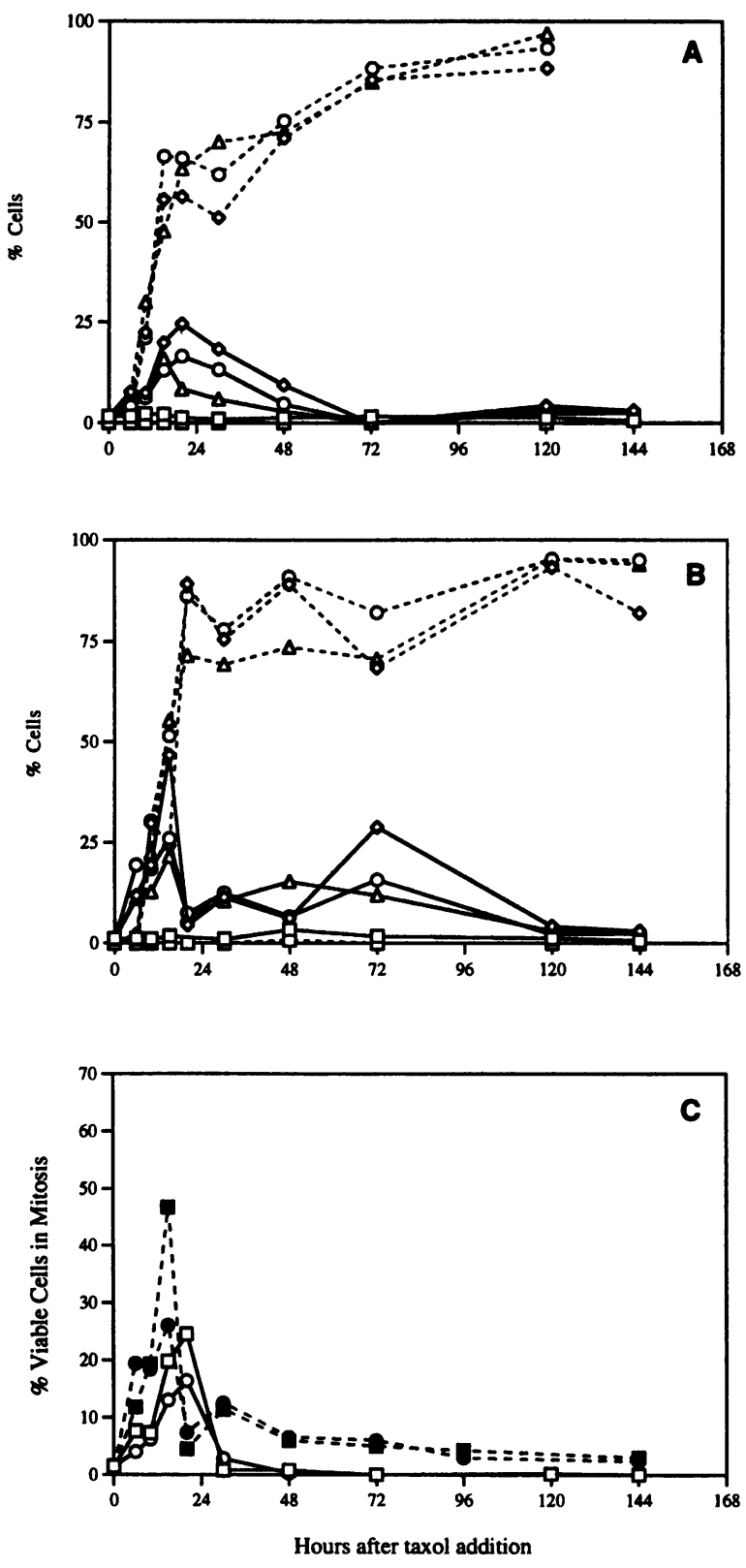

FIG. 7. Comparison of wt p53-expressing MEFs with p53-null MEFs response to taxol.

(A) wt p53 and (B) p53-null MEFs treated with $1 \mu \mathrm{M}(\diamond), 250 \mathrm{nM}(\bigcirc)$, or $100 \mathrm{nM}(\triangle)$ taxol and scored at the indicated times for percentage of cells in prophase (solid lines) and multimininucleation (dotted lines). (C) a comparison of viable cells in $M$ (adherent cells) wt p53 (solid lines) or p53-null MEFs (dotted lines). Taxol concentrations $1 \mu \mathrm{M}(\square)$ and $250 \mathrm{nM}(\mathrm{O})$ are shown.

lines) and the appearance of multimininucleated cells (dashed lines) were similar in both cell lines (Fig. $7 \mathrm{~A}$ and B). However, it was readily apparent that, while normal wt p53-expressing MEFs became blocked in the cell cycle as multimini- 
nucleated cells immediately following passage through aberrant mitosis (i.e., in $G_{1}$ ), multimininucleated p53-/-MEFs continued through several rounds of mitosis in the absence of cytokinesis. Figure 7C represents a comparison of viable cells in mitosis, assayed as number of mitotic cells attached to the coverslip (since those M-blocked cells destined to die detach), following addition of taxol to the cultures. This graph illustrates how wt p53 MEFs (solid lines) cease mitosis after the first wave of mitosis following taxol addition to the cultures, as evidenced by a mitotic index of 0 within $48 \mathrm{hr}$. In particular, all mitotic cells observed in $M$ between 24 and $48 \mathrm{hr}$ were cells with normal chromatin content: multimininucleated wt $\mathrm{p} 53$ cells were never seen to enter mitosis. In contrast, p53-null MEFs (dashed lines) continue to cycle through $M$ throughout the subsequent 6-day period. Furthermore, multimininucleated p53-null MEFs were observed in mitosis throughout the 6-day period. The micrographs in Fig. 8 visualize these differences. The reference size of untreated, control cells in mitosis (indicated by the arrow) and interphase cells is shown in Panels A (Hoechst-stained nuclei) and B (corresponding phase). Those wt p53-expressing MEFs cells in prophase during the first round of mitosis following addition of taxol at $18 \mathrm{hr}$ (indicated by arrowheads in Fig. 8C) compare in size with untreated mitotic cells (indicated by arrow in Fig. 8A above). p53-null MEFs in prophase between 8 and $18 \mathrm{hr}$ and those multimininucleated cells at $18 \mathrm{hr}$ were of identical size to those shown in Panels C and D (data not shown in this figure, but see Fig. 11).

Multimininucleated wt p53 MEFs were never seen in mitosis throughout the detailed observations made during the subsequent 1 - to 6 -day period. Furthermore, those multimininucleated cells remaining attached at 6 days (Fig. 8D) were a similar size with similar chromatin content to multimininucleated cells fixed after $18 \mathrm{hr}$ of taxol treatment (Fig. 8C) indicating arrest in $G_{1}$. In contrast, multimininucleated p53-/- MEFs continued to enter mitosis but as a result of continued aberrant mitosis and lack of cytokinesis, they become progressively larger in size with a progressively greater complement of mini-nuclei (i.e., greater polyploidy; Fig. $8 \mathrm{E}-\mathrm{H}$ ). Compare the size of the mitotic cell after 6 days taxol treatment in Panels $\mathrm{E}$ and $\mathrm{F}$ with the size of cells in mitosis in Panels A, B (control), and C (wt p53 after $18 \mathrm{hr}$ ). The cell indicated by the arrow in Panels $\mathrm{G}$ and $\mathrm{H}$ is just at the onset of chromosome condensation and so clearly reveals the condensation of all the individual mininuclei within the same cell, confirming the entry of multimininucleated cells into M 6 days after taxol treatment. In addition compare the considerably larger size of the multimininucleated cell to the lower left of the cell entering $M$ indicated in Panels $G$ and $H$, seen after 6 days, to the size of the multimininucleated wt p53 cells seen after both $18 \mathrm{hr}$ and 6 days shown in Panels C and D, respectively. FACS analysis was carried out with propidium iodide stained cells that had been fixed after $0 \mathrm{hr}, 24 \mathrm{hr}$, and $72 \mathrm{hr}$ of taxol treatment. This confirmed that only the p53-null MEF population proceeded past the 4N DNA compartment after $24 \mathrm{hr}$ and 3 days of taxol treatment. By 3 days, $70 \%$ of the p53-null MEFs were seen to be in the $8 \mathrm{~N}$ and greater DNA compartment compared with $10 \%$ of untreated cells. In contrast, wt p53-expressing MEFs showed no such trends (data not shown; similar to trends shown by Cross et al. in Ref. 75 for MT destabilizing drugs).

Hoechst-staining revealed that multimininucleated MEFs expressing wt p53 developed all the morphological characteristics of apoptosis between 4 and 5 days following $G_{1}$ arrest: initially, the DNA began to develop more intense punctate staining under the nuclear membrane and subsequently the DNA became highly globular. Little evidence of such changes was observed in p53-null MEFs. TUNEL staining of the two lines

\section{FIG. 8. P53-null MEFs fail to arrest in the $G_{1}$ following the first aberrant mitosis following exposure to} taxol.

wt p53-expressing (A-D) and p53-null (E-H) were treated with $250 \mathrm{nM}$ taxol for 0 (A and B), 18 hr (C), or 6 days (D-H; note that cells were refed taxol-containing medium after 3 days to maintain biologically active levels of taxol) and fixed and stained with Hoechst 33342 (A, C, D, E, and H). The open arrowheads in Panel C indicate the size of prophase nuclei and compare this with the size of the mitotic nucleus indicated in the field of the control cells shown in Panel A (corresponding phase Panel B). This size contrasts markedly with the size of the Hoechst stained p53-null prophase nucleus seen after 6 days of taxol treatment indicated by the arrow in Panel E (corresponding phase Panel F to compare with Panel B). The arrow in Panels $\mathrm{G}$ and $\mathrm{H}$ indicates a cell just beginning chromatin condensation. Bar in Panel $\mathrm{H}$ represents $10 \mu \mathrm{m}$; magnification is the same for all panels. 

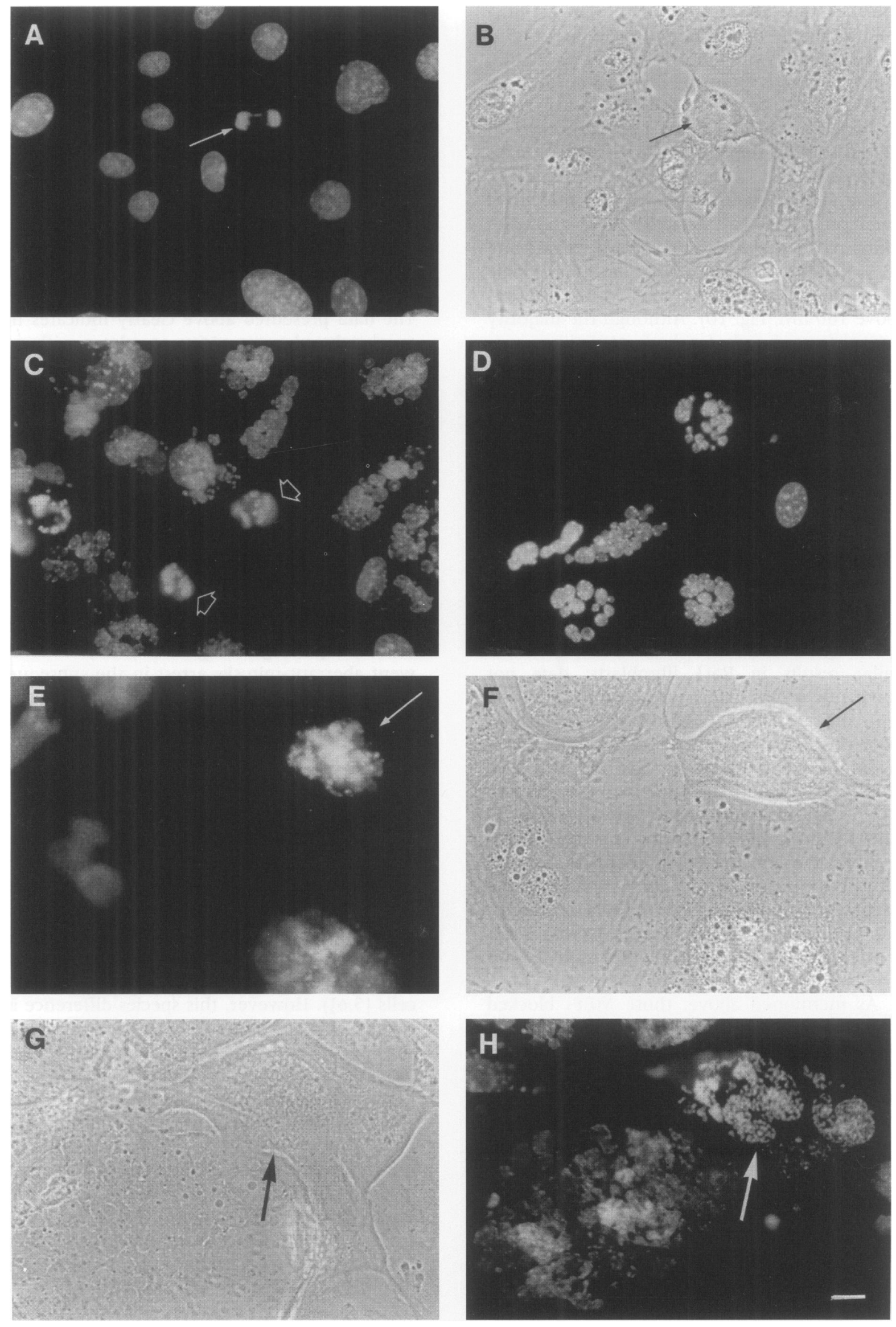
confirmed this difference dramatically. As illustrated in Fig. 9, the multimininuclei in wt p53expressing MEFs all stain very brightly by TUNEL labeling 3-6 days following taxol-induced $G_{1}$ arrest (Fig. 9 A-C represents cells after 6 days taxol treatment). In contrast, the multimininuclei in p53-null MEFs remain negative after 6 days (Fig. 9 D-F).

The above results might predict that taxol would only have a cytostatic effect on MEFs lacking $\mathrm{p} 53$ protein. However, both wt p 53 and p53-I-MEFs showed a similar decline in viable cell numbers at higher taxol concentrations (above $100 \mathrm{nM}$; Fig. 10). Although the majority of taxol-treated cells for both MEF lines succeeded in passaging through an aberrant mitosis, a subset did appear to be completely arrested in prophase at taxol concentrations $\geq 100 \mathrm{nM}$. These detached but rapidly disappeared. Since the numbers of detached, prophase-blocked cells exactly equaled the subsequent (within $2 \mathrm{hr}$ ) drop in cell numbers we concluded they must have been cleared by phagocytotic activity of the adherent interphase fibroblasts. Furthermore, Hoechst staining indicated some vesicular Hoechst staining consistent with an endosomal pattern within the interphase cells at the time points coinciding with the loss of cells. (We observed similar results in Ratl fibroblasts; data not shown.) By comparing the $\mathrm{EC}_{50}$ values for block in $\mathrm{M}$, overall aberrant mitosis and net loss of viable cells with respect to starting numbers, it was immediately apparent that the $\mathrm{EC}_{50}$ for taxol-induced cytotoxicity for both wt p53 and p53-/- MEFs correlate with arrest in early $M$ rather than overall perturbation of mitosis (Table 2 ). Since the appearance of prophase blocked cells is only transient and compounded by the phagocytotic activity of these fibroblasts this correlation is easily missed if detailed scoring is not carried out throughout the critical period of 8-18 hr following addition of taxol.

As mentioned above, those MEFs blocked directly in prophase detached and became nonadherent. Although detachment and Hoechst staining were consistent with these cells being destined for apoptosis, they were too transitory to obtain clearcut morphological evidence of apoptosis. Therefore, we sought to obtain convincing evidence that taxol-induced, early-prophase blocked cells in both MEF lines had initiated apoptosis using TUNEL staining. Cells were fixed after $8-10 \mathrm{hr}$ of exposure to $1 \mu \mathrm{M}$ taxol, while the cells were still adherent (peak detachment of M-blocked cells usually occurred between 10 and $15 \mathrm{hr}$ ) for ease of processing for TUNEL. As shown in Fig. 11, prophase-blocked cells are seen to be TUNEL positive in both wt p53 (Fig. 11, C and D) and p53-null (Fig. $11 \mathrm{E}$ and F) lines and compare with the negative staining of the untreated mitotic cells (Fig. 11, A and B). Also note the multimininucleated cell at the bottom of Panels $C$ and $D$ which is TUNEL negative at this time point.

\section{DISCUSSION}

The data presented above clearly indicates that taxol-induced cytotoxicity correlates with perturbation of mitosis and cell cycle arrest for both the carcinoma lines and the normal HS578Bst line we studied. Our data supports the proposals first made by Kung et al. (Ref. 20, see also Refs. 19 and 23) and Jordan et al. (18) that taxolinduced cytotoxicity correlates with selective perturbation of mitosis rather than gross changes in interphase arrays as proposed by Rowinsky et al. (8) based on their studies of taxol effects on leukemic lines. We detected two forms of taxolinduced cell cycle arrest: arrest in prophase at the $\mathrm{G}_{2} / \mathrm{M}$ transition and, for those cells that succeeded in passing through this block and underwent aberrant mitosis; arrest in the subsequent $G_{1}$ stage. For all the human cell lines that we examined, the major fraction of the population entering $M$ during the time period taxol remained effective became arrested in prophase, with only a minor fraction becoming arrested in $\mathrm{G}_{1}$ as multimininucleated cells. As noted previously by others, we found rodent cells to be more tolerant of mitotic arrest per se than human lines $(5,6,18,23)$. Rather the majority of the population proceeded through a dysfunctional mitosis to become arrested in $G_{1}$ as multimininucleated cells (the restitution nuclei described by DeBrabander et al. in their studies on rodent PtK2 cells $[5,6])$. However, this species difference is a relative difference rather than an absolute one since we demonstrate here that rodent cells also displayed taxol-induced arrest in early $M$ but at higher taxol concentrations than the $\mathrm{EC}_{50}$ for aberrant $M$ and subsequent $G_{1}$ arrest. As we have shown, this can be readily missed due to the transitory nature of the detached prophaseblocked cells due to phagocytosis by the adherent interphase cells. Both forms of cell cycle arrest led to cell death which by all morphological and DNA gel criteria occurred by apoptosis irrespective of the species cell type studied. 

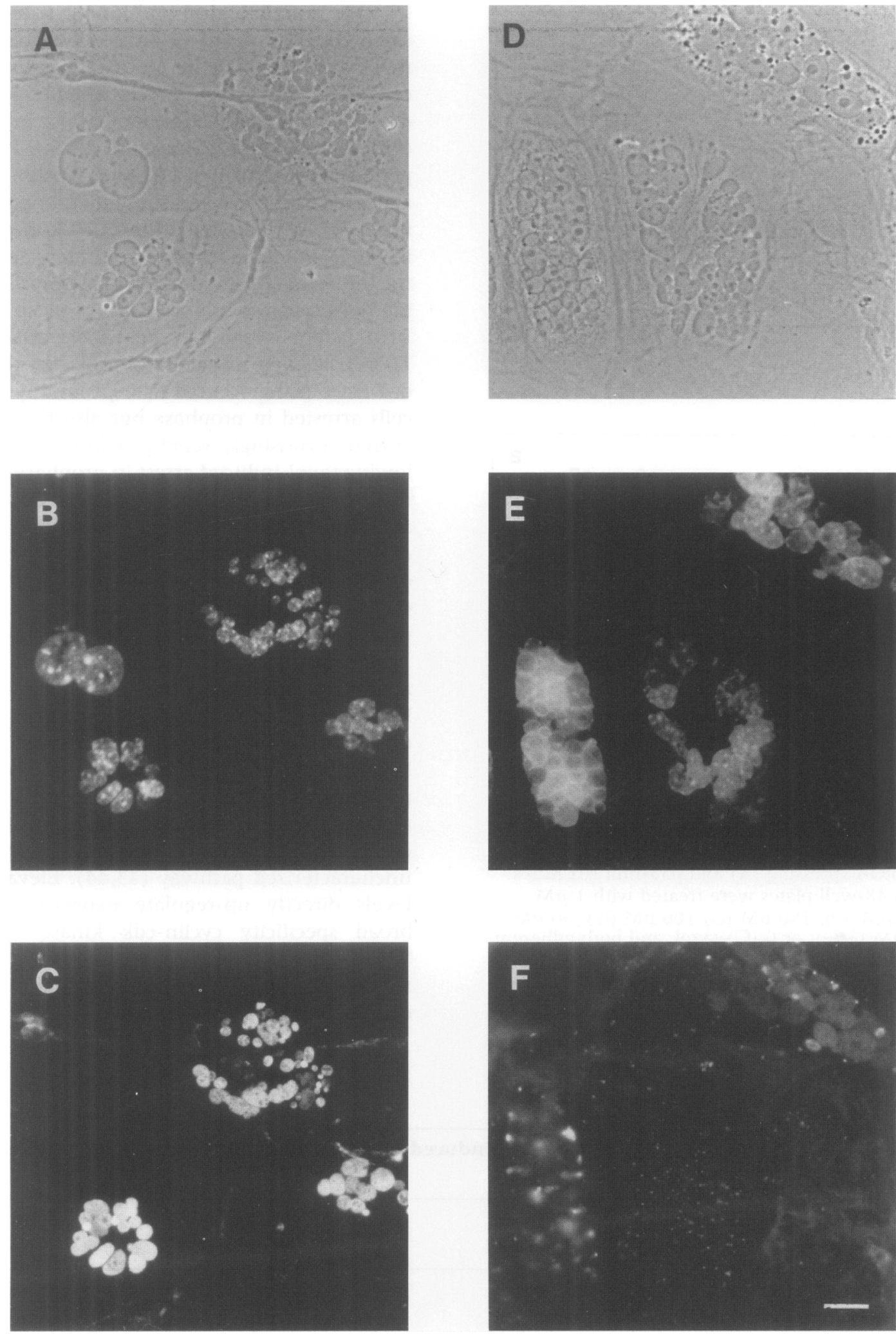

FIG. 9. Multimininucleated p53-null MEFs fail to become TUNEL positive

wt p53-expressing (A-C) or p53-null (D-F) MEFs were treated for 6 days with $250 \mathrm{nM}$ taxol, then processed for TUNEL ( $C$ and F) and counterstained with DAPI ( $B$ and E). Phase images of the same fields are shown in Panels A and D. Bar in Panel F represents $10 \mu \mathrm{m}$; magnification is the same for all panels. 

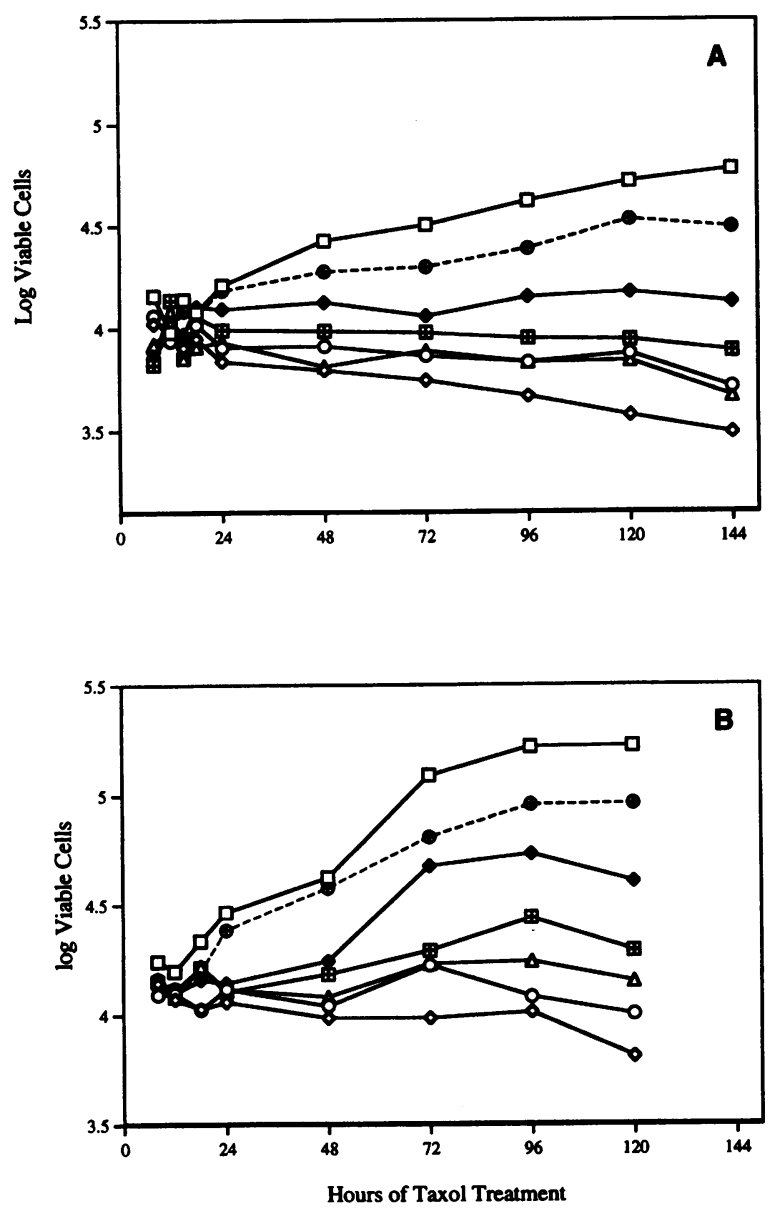

FIG. 10. At $\mu M$ taxol concentrations, both p53-expressing and -null MEFs exhibit a similar taxol-induced decline in cell number

Normal p53-expressing (A) and p53-null (B) MEFs grown in 48-well plates were treated with $1 \mu \mathrm{M}$ $(\diamond), 250 \mathrm{nM}(\bigcirc), 150 \mathrm{nM}(\triangle) 100 \mathrm{nM}(\boxplus), 50 \mathrm{nM}$ (४), $25 \mathrm{nM}(--)$, or 0 ( $\square)$ taxol, and both adherent and detached cells in triplicate wells were counted at the indicated time intervals. Data is plotted as log cell number.
Our morphological and kinetic studies indicated that cell death occurred more rapidly in those cells arrested in M. Multimininucleated cells died with much slower kinetics over 3-7 days following taxol treatment. Those interphase cells that did not passage $M$ during the time period taxol remained effective (within $48 \mathrm{hr}$ ), appeared to survive and subsequently proliferate normally. We employed the TUNEL method for in situ DNA end labeling to accurately determine the time course for induction of apoptosis following both types of cell cycle arrest, since classical DNA ladders were only detectable after $24 \mathrm{hr}$. TUNEL labeling revealed not only that the onset of DNA nicking occured first specifically in those cells arrested in prophase but also that this occurred surprisingly rapidly; within $30 \mathrm{~min}$ following taxol-induced arrest in prophase. In contrast, those cells that progressed through aberrant mitosis and were arrested in the subsequent $G_{1}$ stage, became TUNEL positive only $2-4$ days following $G_{1}$ arrest. This was similar for all the human cell types examined, as well as Rat 1 (data not shown) and wt p53-expressing MEFs.

The majority of commonly used cancer therapeutic agents, including $\gamma$-irradiation, cause DNA damage and have been shown to exert their cytotoxic effects by triggering apoptosis (35-43). DNA nicking has been shown to directly elevate p53 protein expression which in turn induces arrest in the subsequent $G_{1}$ or $G_{2}$ stage of the cell cycle and then activates apoptosis by an as yet uncharacterized pathway $(43,44)$. Elevated p53 levels directly up-regulate expression of the broad specificity cyclin-cdk kinase inhibitor, WAF1/Cipl/p21 $(45-48,54,74)$ which appears to mediate the p53-dependent inhibition of cyclin-dependent kinase activities in $G_{1}$ following

TABLE 2. Comparison of $\mathrm{EC}_{50}$ values for taxol-induced mitotic effects and cytotoxicity between \pm p53 MEF phenotypes

\begin{tabular}{lccr}
\hline Cell Type & $\begin{array}{c}\text { Mitotic Arrest } \\
\text { (nM) }\end{array}$ & $\begin{array}{c}\text { Aberrant Mitosis }^{a} \\
\text { (nM) }\end{array}$ & $\begin{array}{c}\text { Cytotoxicity }^{b} \\
\text { (nM) }\end{array}$ \\
\hline wt p53 MEF & $135.6 \pm 9.6$ & $46.2 \pm 5.3$ & $95.4 \pm 32$ \\
p53 - - MEF & $120.0 \pm 6.1$ & $47.2 \pm 0.1$ & $110.7 \pm 17.4$ \\
\hline
\end{tabular}

${ }^{a}$ Scoring after $24 \mathrm{hr}$.

${ }^{b}$ Determinations based on absolute decline in total cell number after 6 days with respect to starting numbers at time of taxol addition. 

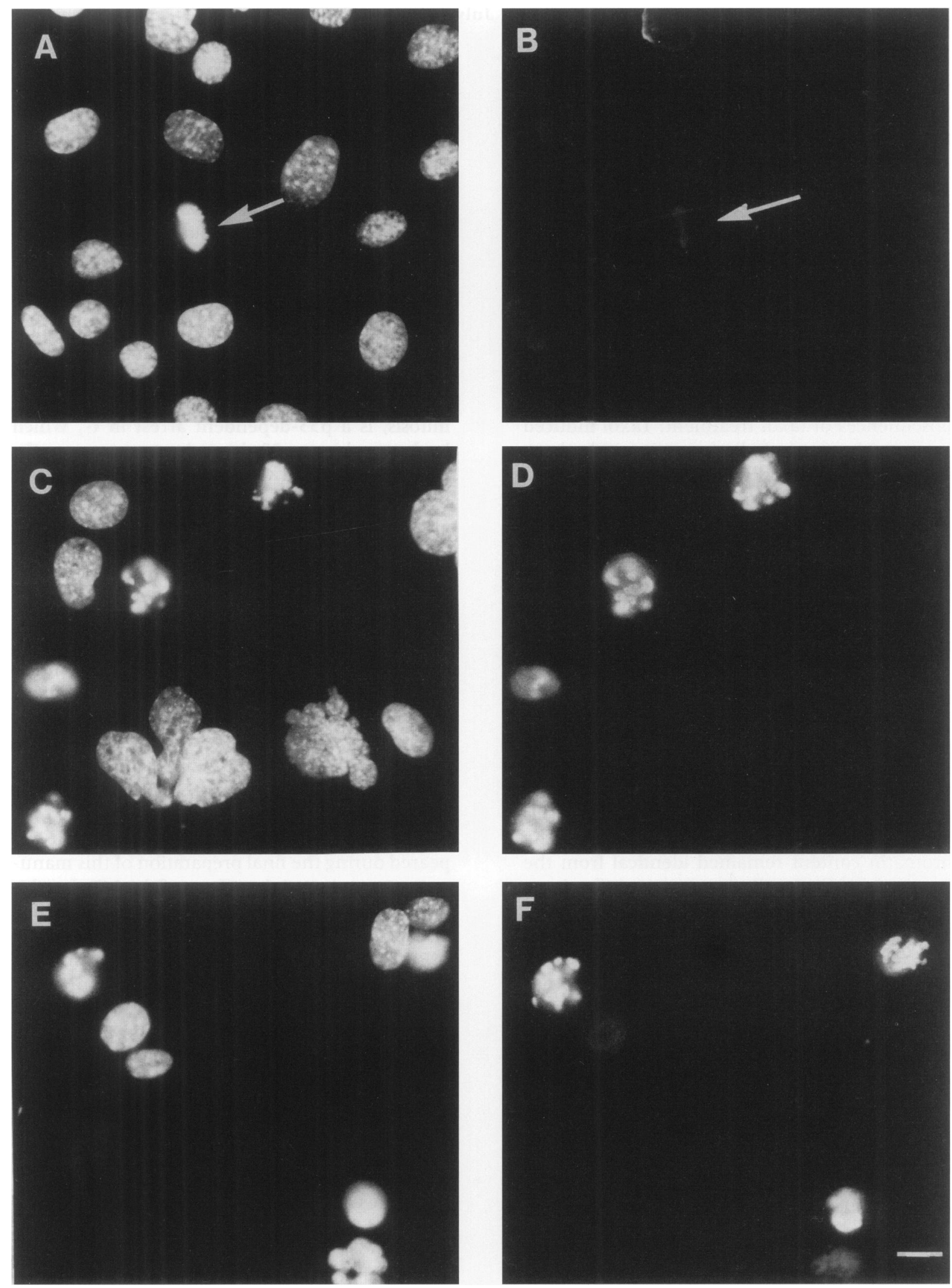

FIG. 11. Taxol-induced prophase-blocked wt p53 and p53-null MEFs both exhibit signs of apoptosis wt-expressing MEFs (A, B, C, and D) and p53-null MEFs (E and F) were treated with 0 (A and B) or $1 \mu \mathrm{M}$ taxol (C-F) for $8 \mathrm{hr}$ prior to fixation and processing for TUNEL (B, D, and F) and counterstained with DAPI (A, C, and E). Arrow in Panels A and B indicates a control cell in metaphase. Bar in Panel F represents $10 \mu \mathrm{m}$; magnification is the same for all panels. 
$\gamma$-irradiation $(45,47,54,62)$. The $G_{2}$ block induced by many DNA-damaging antineoplastic agents entails a similar p53-mediated up-regulation of WAF1/Cipl/p21 (41,54).

Since taxol exhibits a completely different mechanism of action to the other antineoplastic agents, binding specifically to and thereby stabilizing intracellular MTs (1-4), which in turn induces predominantly arrest in $M(1,3,26)$, we examined the role of p53 in taxol-induced apoptosis. For this we chose to compare MEFs expressing wt p53 with MEFs with a null p53 phenotype for an unambiguous answer. As expected, p53 status did not affect the primary consequences of taxol treatment. Taxol induced the same aberrant spindle formation in both $\mathrm{wt}$ p53 and p53-null MEFs. This led to a subset $(\sim 1 / 3)$ of cells exhibiting true arrest in prophase at relatively high taxol concentrations $\left(\mathrm{EC}_{50} \sim\right.$ $130 \mathrm{nM}$ ) and the remainder proceeding through aberrant mitosis to become multimininucleated cells $\left(\mathrm{EC}_{50} \sim 46 \mathrm{nM}\right)$. However, whereas the wt p53-expressing MEFs became arrested in this first $G_{1}$, the p53-null MEFs failed to arrest. They continued to progress through several rounds of the cell cycle in the absence of cytokinesis, becoming progressively larger with a progressively larger complement of mininuclei. Detailed morphological studies by Hoechst-chromatin staining of treated cell populations strongly suggested the wt p53-expressing multimininucleated cells became immediately arrested in $G_{1}$ since the chromatin content remained identical from the time these aberrant cells first appeared (i.e., bona fide $G_{1}$ ) to all subsequent time points. This was confirmed by FACS analysis. Studies on similar p53 $+1+$ and p53-1- cell lines by Cross et al. (75), but using the MT-destabilizing agents nocodazole and colcemid, gave FACS DNA content data that was identical to the data we obtained with taxol-treated MEFs. Both by morphological criteria and by TUNEL labeling it was evident that multimininucleated $\mathrm{wt}$ p53-expressing MEFs developed all the hallmarks of apoptotic cell death. In contrast, the multimininucleated p53-null MEFs failed to exhibit signs of apoptotic death throughout the following 7-day period. Despite this, higher taxol concentrations induced a similar decline in total viable cell number in both lines rather than exerting solely a cytostatic effect in the p53 null line as might be predicted from the above observations. Detailed morphological characterization throughout the time course of the first cell cycle $(\sim 15-18 \mathrm{hr})$ revealed that in fact this decline in viable cells correlated with the $\mathrm{EC}_{50}$ for arrest in prophase which was similar for both MEF lines. TUNEL staining of the two MEF lines confirmed that a subset of cells seen in prophase after $10 \mathrm{hr}$ of taxol treatment did initiate DNA nicking, indicative of the induction of apoptosis.

Taken together, our results indicate that the antineoplastic mechanism of action of taxol evokes two distinct apoptotic pathways. The first is triggered by arrest in prophase at the $G_{2} M$ transition which leads to the rapid activation (within $30 \mathrm{~min}$ ) of a p53-independent apoptotic pathway. The second, manifested by those cells that succeed in progressing through an aberrant mitosis, is a p53-dependent arrest in $G_{1}$ which leads to a slower $\mathrm{p} 53$-dependent apoptotic pathway. We observed $G_{1}$ arrest at taxol concentrations around the $\mathrm{EC}_{50}$ values for mitotic effects in all the human lines, albeit for a very small percent for the faster growing HeLa and Hs578T cells. Yet, Hs578T cells have been shown to harbor mutant p53 carrying a point mutation (67). Since mutant forms of $\mathrm{p} 53$ have been shown to have potential "gain of function" activity (63-64), it is clear that $\mathrm{p} 53$ protein carrying a point mutation is not synonymous with a null phenotype. Recently, it has been shown that antineoplastic agents may still be effective at inducing up-regulated expression of WAF1/Cipl/p21, the downstream effector of $p 53$-mediated $G_{1}$ or $G_{2}$ arrest, in cell lines carrying point mutations in p 53 (77).

The study by Cross et al. (75), which appeared during the final preparation of this manuscript, investigated the effects of the MT-destabilizing drugs, nocodazole and colcemid, which also perturb mitosis, on p53+1+ and p53-null MEFs. Although the data convincingly showed that wt p53 MEFs became arrested with 4N DNA content, but p53-null MEFs failed to arrest and accumulated progressively increasing amounts of DNA, the authors concluded that this data indicated that p53 was essential for a spindle checkpoint in $\mathrm{M}$. However, the $4 \mathrm{~N}$ DNA compartment was not subdivided into normal $G_{2}$, cells in $M$ and multimininucleated cells. Therefore, the data could indicate equally well that only the arrest in $G_{1}$ following aberrant mitosis is compromised by the absence of $\mathrm{p} 53$. The detailed microscopic analyses we present here, clearly show that for taxol concentrations $\geq 100 \mathrm{nM}$, nearly all cells remaining after $24 \mathrm{hr}$ are multimininucleated cells, so represent cells that have passaged aberrant mitosis to become aberrant $4 \mathrm{~N}$ DNA-containing cells in $G_{1}$. Since MT-destabilizing drugs effect a similar $M$ and $G_{1}$ block to taxol 
$(18-20,22)$, it is clear the accumulation of cells in the $4 \mathrm{~N}$ DNA compartment observed by Cross et al. (75) actually represent multimininucleated cells after $24 \mathrm{hr}$. By accounting for the fate of all the cells, which revealed the loss of M-blocked cells by phagocytosis, and titrating a taxol concentration that can effect a block in $M$ at prophase in these murine cells, the data presented here in this report indicates that in fact the mitotic checkpoint is independent of $\mathrm{p} 53$ status. Our preliminary observations indicate that cyclin B levels are higher in taxol-blocked prophase cells than in normal cells in prophase through metaphase (data not shown). Further experimentation is required to determine whether this is indicative of heightened $\mathrm{p} 34^{\mathrm{cdc} 2}$ / cyclin B kinase activity. However, these observations are interesting in light of the following observations: (1) prolonged $\mathrm{p} 34^{\mathrm{cdc} 2} /$ cyclin $\mathrm{B}$ kinase activity might underly colcemid cytotoxicity $(45,46) ;(2)$ an increase in $\mathrm{p} 34^{\mathrm{cdc} 2} /$ cyclin B kinase activity is observed just prior to cell death after cisplatin-induced $G_{2}$ block (i.e., downstream from the initial $\mathrm{p} 53-\mathrm{WAF} 1 / \mathrm{Cipl} / \mathrm{p} 21 \mathrm{re}-$ sponse effecting the $G_{2}$ arrest $[39,41]$ ); (3) initiation of apoptosis involves p34 ${ }^{\text {cdc2 }}$ kinase activation (78) and up-regulation of cyclin A $(79,80)$; and (4) deletion of the wee ${ }^{1}$ kinase responsible for maintaining the $\mathrm{p} 34^{\mathrm{cdc}^{2}}$ kinase in a phosphorylated inactive form (81) induces a "mitotic catastrophe" state that bears all the morphological features of taxol-blocked apoptotic cells in prophase (82). It remains to be shown whether, indeed, arrest in $M$ directly activates a $\mathrm{p} 34^{\mathrm{cdc} 2}$ kinase apoptotic response, in comparison with the p53-WAF1/Cipl/p21-dependent response that effects $G_{1}$ block by inhibition of cyclin/cdk kinase activities well in advance of the active process of apoptosis.

Both p53-dependent and -independent pathways of apoptosis have been shown exist. While the former clearly operate in response to DNA damage resulting from $\gamma$-irradiation and DNA damaging agents (35-43), apoptotic pathways operating in normal development resulting from growth factor deprivation function through p53independent pathways $(52,54,68)$. Our data suggest that direct block in prophase also bypasses a p53-WAF1/Cipl/p21-dependent pathway. This could provide some explanation as to why taxol, uniquely among all the chemotherapeutic agents utilized to date, has shown efficacy against advanced stage, drug refractory leukemia, ovarian, and metastatic breast cancers (9-12). A high proportion of many types of advanced solid tumor types express mutant p53 $(55-59,63,64)$. Thus, the commonly used cancer therapeutic agents that induce DNA damage and thereby directly activate the p53-dependent apoptotic pathway would be predicted to be ineffective against late-stage tumors consisting of clonally expanded, p53 mutantexpressing cells. By inducing a rapidly activating, M-block-dependent apoptotic pathway that is $\mathrm{p} 53$ independent (and presumably WAF1/Cipl/p21independent), taxol may therefore bypass at least this one common pathway of aquired resistance to antineoplastic agents. The MT destabilizing drugs (e.g., vinblastine, vincristine, colchicine, podophyllotoxin) also appear to induce cell cycle arrest specifically in $M$, but to date their use in the clinic has been restricted by a poor therapeutic index. Although taxol appears to have an improved therapeutic index and to be efficacious for a broader spectrum of cancer types, its use is still limited by its poor solubility and side effect profile. Therefore, the discovery of additional structural classes of antineoplastic agents that exhibit a mechanism of action similar to that of taxol and specifically induce arrest in M-phase (73), but have the potential for an improved side effect and solubility profile, might prove highly useful in the fight against cancer.

\section{ACKNOWLEDGMENTS}

We greatly appreciate the assistance of Judy Miller in carrying out FACS analysis and also thank J. Xu for helpful discussions on the TUNEL method and Dr. Helen Ranney for valuable input during the completion of this manuscript.

\section{REFERENCES}

1. Schiff PB, Horwitz SB. (1980) Taxol stabilizes microtubules in mouse fibroblast cells. Proc. Natl. Acad. Sci. U.S.A. 77: 1561-1565.

2. Schiff PB, Horwitz SB. (1981) Taxol assembles tubulin in the absence of exogenous guanosine 5-triphosphate or microtubule-associated proteins. Biochemistry 20: 3247-3252.

3. Manfredi JJ, Horowitz SB. (1984) Taxol: An antimitotic agent with a new mechanisms of action. Pharmacol. Ther. 25: 83-125.

4. Manfredi JJ, Parness J, Horwitz SB. (1982) Taxol binds to cellular microtubules. J. Cell Biol. 94: 688-696.

5. De Brabander $M$, Geuens $G$, Nuydens $R$, Willebrords R, De Mey J. (1981) Taxol induces the assembly of free microtubules in 
living cells and blocks the organizing capacity of the centrosomes and kinetochores. Proc. Natl. Acad. Sci. U.S.A. 78: 5608-5612.

6. De Brabander $M$, Geuens G, Nuydens $R$, Willebrords F, Aerts F, DeMey J. (1986) Microtubule dynamics during the cell cycle: The effects of taxol and nocodazole on the microtubule system of Pt $\mathrm{K} 2$ cells at different stages of the mitotic cycle. In: Bourne GH, Danielli JF, Jeon KW, (eds). Int. Review of Cytology. Academic Press, Orlando, pp. 215-274.

7. Howard WD, Timasheff SN. (1988) Linkages between the effects of taxol, colchicine, and GTP on tubulin polymerization. J. Biol. Chem. 263: 1342-1346.

8. Rowinsky EK, Donehower RC, Jones RJ, Tucker RW. (1988) Microtubule changes and cytotoxicity in leukemic cell lines treated with taxol. Cancer Res. 48: 4093-4100.

9. McGuire WP, Rowinsky EK, Rosenshein NB, et al. (1989) Taxol: A unique antineoplastic agent with significant activity in advanced ovarian epithelial neoplasms. Ann. Intern. Med. 111: 273-279.

10. Rowinsky EK, Cazenave LA, Burke PJ, et al. (1989) Phase I and pharmacodynamic study of taxol in refractory acute leukemias. Cancer Res. 49: 4640-4647.

11. Adler LM, Herzog TJ, Williams S, Rader JS, Mutch DG. (1994) Analysis of exposure times and dose escalation of paclitaxel in ovarian cancer cell lines. Cancer 74: 1891-1898.

12. Holmes FA, Walters RS, Theriault RL, et al. (1991) Phase II trial of taxol, an active drug in the treatment of metastatic breast cancer. J. Natl. Cancer Inst. (U.S.A.) 83: 797-805.

13. Ettinger DS. (1993) Overview of paclitaxel (Taxol) in advanced lung cancer. Sem. Oncology 20: $46-49$.

14. Wiernik PH, Schwartz EL, Einzig A, Strauman JJ, Lipton RB, Dutcher JP. (1987) Phase I trial of taxol given as a 24-hour infusion every 21 days: Responses observed in metastatic melanoma. J. Clin. Oncol. 5: 1232-1239.

15. Einzig AI, Hochster $\mathrm{H}$, Wiernik $\mathrm{PH}$, et al. (1991) A phase II study of taxol in patients with malignant melanoma. Inv. New Drugs 9: 59-64.

16. Forastiere AA. (1993) Use of paclitaxel (Taxol) in squamous cell carcinoma of the head and neck. Sem. Oncology 20: 56-60.

17. Dustin P. (1984) Microtubules. 2nd Ed. Springer-Verlag, Berlin.

18. Jordan MA, Toso RJ, Thrower D, Wilson L. (1993) Mechanism of mitotic block and in- hibition of cell proliferation by taxol at low concentrations. Proc. Natl. Acad. Sci. U.S.A. 90: 9552-9556.

19. Kung AL, Sherwood SW, Schimke RT. (1990) Cell line-specific differences in control of cell cycle progression in the absence of mitosis. Proc. Natl. Acad. Sci. U.S.A. 87: 95539557.

20. Kung AL, Zetterberg A, Sherwood AW, Schimke RT. (1990) Cytotoxic effects of cell cycle phase specific agents: a result of cell cycle perturbation. Cancer Res. 50: 7307-7314.

21. Liebmann JE, Cook JA, Lipschultz C, Teague D, Fisher J, Mitchell JB. (1993) Cytotoxic studies of paclitaxel (Taxol) in human tumour cell lines. Br. J. Cancer 68: 1104-1 109.

22. Sherwood SW, Sheridan JP, Schimke RT. (1994) Induction of apoptosis by the antitubulin drug colcemid: Relationship of the mitotic checkpoint control on the induction of apoptosis in HeLa S3 cells. Exp. Cell Res. 215: 373-379.

23. Bailly E, Dorée $M$, Nurse $P$, Bornens $M$. (1989) p34 $4^{\text {cdc2 }}$ located in both nucleus and cytoplasm; Part is centrosomally associated at $\mathrm{G}_{2} / \mathrm{M}$ and enters vesicles at anaphase. E.M.B.O. J. 8: 3985-3995.

24. Brinkley BR. (1985) Microtubule organizing centers. Annu. Rev. Cell Biol. 1: 145-172.

25. Verde F, Labbé J, Dorée M, Karsenti E. (1990) Regulation of microtubule dynamics by cdc2 protein kinase in cell-free extracts of Xenopus eggs. Nature 343: 223-238.

26. Fuchs DA, Johnson RK. (1978) Cytologic evidence that taxol, an antineoplastic agent from Taxus brevifolia, acts as a mitotic spindle poison. Cancer Treat. Rep. 62: 1219-1224.

27. Liebmann JE, Cook JA, Lipschultz C, Teague D, Fisher J, Mitchell JB. (1994) The influence of Cremophor E.L. on the cell cycle effects of paclitaxel (Taxol) in human cell lines. Cancer Chemother. Pharmacol. 33: 331-339.

28. Lopes NM, Adams EG, Pitts TW, Bhuyan KB. (1993) Cell kill kinetics and cell cycle effects of taxol on human and hamster ovarian cell lines. Cancer Chemother. Pharmacol. 32: 235-242.

29. Hruban RH, Yardley JH, Donehower RC, Boitnott JK. (1988) Epithelial necrosis in the gastrointestinal tract associated with polymerized microtubule accumulation and mitotic arrest. Cancer 63: 1944-1950.

30. Rowinsky EK, Eisenhauer EA, Chaudhry V, Arbuck SG, Donehower RC. (1993) Clinical toxicities encountered with paclitaxel (Taxol). Semin. Oncol. 20: 1-5. 
31. Stearns M, Wang M. (1992) Taxol blocks processes essential for prostate tumor cell growth, invasion and metastases. Cancer Res. 52: 3776-3781.

32. Kerr JFR, Wyllie AH, Currie AR. (1972) Apoptosis: A basic biological phenomenon with wide-ranging implications in tissue kinetics. Br. J. Cancer 26: 239-257.

33. Wyllie AH. (1981) Cell death: A new classification separating apoptosis from necrosis. In: Bowen ID, Lockshin RA, (eds.). Cell Death in Biology and Pathology. Chapman \& Hall, London, pp. 9-34.

34. Wyllie AH. (1994) Death from inside out: an overview. Phil. Trans. Royal Soc. London (B) 345: 237-241.

35. Sachs L, Lotem J. (1992) Control of programmed cell death in normal and leukemic cells: New implications for therapy. Blood 82: 15-21.

36. Schwartzman RA, Cidlowski JA. (1993) Apoptosis: The biochemistry and molecular biology of programmed cell death. Endocr. Rev. 14: 133-151.

37. Barry MA, Behnke CA, Eastman A. (1990) Activation of programmed cell death (apoptosis) by cisplatin, other anticancer drugs, toxins and hyperthermia. Biochem. Pharmacol. 40: 2353-2362.

38. Hickman JA, Potten CS, Merritt AJ, Fisher TC. (1994) Apoptosis and cancer chemotherapy. Phil. Trans. Royal Soc. London (B) 343: 319-325.

39. Sen S, D'Incalci M. (1992) Biochemical events and relevance to cancer chemotherapy. Fed. Eur. Biochem. Soc. Lett. 307: 122-127.

40. Demarcq C, Bunch RT, Creswell D, Eastman A. (1993) The role of cell cycle progression in cisplatin-induced apoptosis in Chinese hamster ovary cells. Cell Growth Diff. 5: 983-993.

41. O'Connor PM, Ferris DK, White GA, et al. (1992) Relationships between cdc2 kinase, DNA cross-linking and cell cycle perturbations induced by nitrogen mustard. Cell Growth Diff. 3: 43-52.

42. Lowe SW, Ruley HE, Jacks T, Housman DE. (1993) p53-Dependent apoptosis modulates the cytotoxicity of anticancer agents. Cell 74: 957-967.

43. Kastan MB, Onyekwere O, Sidransky D, Vogelstein B, Craig RW. (1991) Participation of p53 protein in the cellular response to DNA damage. Cell 74: 957-967.

44. Nelson WG, Kastan MB. (1994) DNA strand breaks: The DNA template alterations that trig- ger p53-dependent DNA damage response pathways. Mol. Cell. Biol. 14: 1815-1823.

45. El-Deiry WS, Tokino T, Velculescu VE, et al. (1993) WAFl, a potential mediator of p53 tumor suppression. Cell 75: 817-825.

46. Gu Y, Turc CW, Morgan DO. (1993) Inhibition of CDK2 activity in vivo by an associated 20K regulatory subunit. Nature 366: 707-710.

47. Harper JW, Adami GR, Wei N, Keyomarsi K, Elledge SJ. (1993) The p2l Cdk-interacting protein Cipl is a potent inhibitor of Gl cyclin-dependent kinases. Cell 75: 805-816.

48. Dulic W, Kaufmann WK, Wilson SJ, et al. (1994) p53-dependent inhibition of cyclindependent kinase activities in human fibroblast during radiation-induced $G_{1}$ arrest. Cell 76: 1013-1033.

49. Fritsche M, Haessler C, Brandner G. (1993) Induction of nuclear accumulation of the tumor suppressor protein $\mathrm{p} 53$ by DNA-damaging agents. Oncogene 8: 307-318.

50. Lu X, Lane DP. (1993) Differential induction of transcriptionally active $\mathrm{p} 53$ following UV or ionizing radiation: defects in chromosome instability syndromes? Cell 75: 765-778.

51. Clarke AR, Purdie CA, Harrison DJ, et al. (1993) Thymocyte apoptosis induced by p53-dependent and independent pathways. Nature 362: 849-852.

52. Lee JM, Bernstein A. (1993) p53 mutations increase resistance to ionizing radiation. Proc. Natl. Acad. Sci. U.S.A. 90: 5742-5746.

53. Lowe SW, Schmitt EM, Smith SW, Osborne BA, Jacks T. (1993) p53 is required for radiation-induced apoptosis in mouse thymocytes. Nature 362: 847-849.

54. El-Deiry WS, Harper JW, O'Connor PA, et al. (1994) WAFl/Cipl is induced in p53mediated Gl arrest and apoptosis. Cancer Res. 53: $1168-1174$.

55. Levine AJ, Momand J, Finlay CA. (1991) The p53 tumour suppressor gene. Nature 351: 453-456.

56. Fearon ER, Vogelstein B. (1990) A genetic model for colorectal tumorigenesis. Cell 61: 759-767.

57. Hollstein M, Sidransky D, Vogelstein B, Harris CC. (1991) p53 Mutations in human cancers. Science 253: 49-53.

58. Sidransky D, Mikkelsen T, Schwechheimer KM, Rosenblum L, Cavanee W, Vogelstein B. (1992) Clonal epansion of p53 mutant cells is associated with brain tumour progression. Nature 355: 846-847.

59. Hartwell L. (1992) Defects in a cell cycle 
checkpoint may be responsible for the genomic instability of cancer cells. Cell 71: 543-546.

60. Jenkins JR, Rodge K, Chumskev P, Currie GA. (1986) The cellular oncogene $\mathrm{p} 53$ can be activated by mutagenesis. Nature 317: 816-818.

61. Yin Y, Tainsky MA, Bischoff FZ, Strong LC, Wahl GM. (1992) Wild-type p53 restores cell cycle control and inhibits gene amplication in cells with mutant p53 alleles. Cell 70: 937-948.

62. Perry ME, Levine AJ. (1994) p53 and mdm-2: Interactions between a tumor suppressor gene and oncogene product. Mt. Sinai J. Med. 61: 291-299.

63. Zambetti GP, Levine AJ. (1993) A comparison of biological activities of wild type and mutant p53. F.A.S.E.B. J. 7: 855-865.

64. Dittmer D, Patti S, Zambetti G, et al. (1993) Gain of function mutations in p53. Nature Genet. 4: 42-46.

65. Sturzbecker HW, Brain R, Addison C, et al. (1992) A C-terminal $\alpha$-helix plus basic region motif is the major structural determinant of p53 tetramerization. Oncogene 7: 1513-1523.

66. Donehower LA, Harvey $M$, Slagle $B L$, et al. (1992) Mice deficient for p53 are developmentally normal but susceptible to spontaneous tumours. Nature 356: 215-221.

67. Symonds $H$, Krall L, Remington L, et al. (1994) p53-Dependent apoptosis suppresses tumor growth and progression in vivo. Cell 78: 703-711.

68. Berges RR, Furuya Y, Remington L, English HF, Jacks T, Isaacs JT. (1993) Cell proliferation, DNA repair and $\mathrm{p} 53$ function are not required for programmed death of prostatic glandular cells induced by androgen ablation. Proc. Natl. Acad. Sci. U.S.A. 90: 8910-8914.

69. Bhalla K, Ibrado AM, Tourkina E, Tang C, Mahoney ME, Huang Y. (1993) Taxol induces internucleosomal DNA fragmentation associated with programmed cell death in human myeloid leukemia cells. Leukemia 7: 563-568.

70. Willingham MC, Bhalla K. (1994) Transient mitotic phase localization of Bcl-2 oncoprotein in human carcinoma cells and its possible role in prevention of apoptosis. J. Histochem. Cytochem. 42: 441-450.

71. Donaldson KL, Goolsby G, Kiener PA, Wahl
AF. (1994) Activation of $\mathrm{p} 34^{\mathrm{cdc} 2}$ coincident with taxol-induced apoptosis. Cell Growth Differen. 5: 1041-1050.

72. Gavrieli Y, Sherman Y, Ben-Sasson SA. (1992) Identification of programmed cell death in situ via specific labeling of nuclear DNA fragmentation. J. Cell Biol. 119: 493-501.

73. Bollag D, McQueney PA, Zhu J, Hensens O, Koupal L, Liesch J, Goetz M, Lazarides E, Woods CM. (in press) Epothilones: A novel class of microtubule stabilizing agents with a taxol-like mechanism of action. Cancer Res. 55: 2325-2333.

74. Xiong Y, Hannon GJ, Zhang H, Casso D, Kobayashi R, Beach D. (1993) p21 is a universal inhibitor of cyclin kinases. Nature 366: 701-704.

75. Cross SM, Sanchez CA, Morgan CA, et al. (1995) A p53-dependent mouse spindle checkpoint. Science 267: 1363-1367.

76. Runnebaum IB, Nagarajan M, Bowman M, Soto D, Sukumar S. (1991) Mutations in p53 as potential molecular markers for human breast cancer. Proc. Natl. Acad. Sci. U.S.A. 88: 10657-10661.

77. Sheikh MS, Li X, Chen J, Shao Z, Ordonez JV, Fontana JA. (1994) Mechanisms of regulation of WAFl/Cipl gene expression in human breast carcinoma: Role of p53-dependent and independent signal transduction pathways. Oncogene 9: 3407-3415.

78. Shi L, Nishioka WK, Th'ng J, Bradbury EM, Lichfiel DW, Greenberg AH. (1994) Premature $\mathrm{p} 34^{\mathrm{cdc} 2}$ activation required for apoptosis. Science (Wash. D.C.), 263: 1143-1 145.

79. Hoang AT, Cohen KJ, Barrett JF, Bergstrom DA, Dang CV. (1994) Participation of cyclin A in Myc-induced apoptosis. Proc. Natl. Acad. Sci. U.S.A. 91: 6875-6879.

80. Meikrantz W, Gisselbrecht S, Tam SW, Schlegel R. (1994) Activation of cyclin A-dependent protein kinases during apoptosis. Proc. Natl. Acad. Sci. U.S.A. 91: 3754-3758.

81. Russell P, Nurse P. (1987) Negative Regulation of Mitosis by wee $1^{+}$, a gene encoding a protein kinase homolog. Cell 49: 559-567.

82. Heald R, McLoughlin M, McKeon F. (1993) Human Weel maintains mitotic timing by protecting the nucleus from cytoplasmically activated Cdc2 kinase. Cell 74: 463-474. 